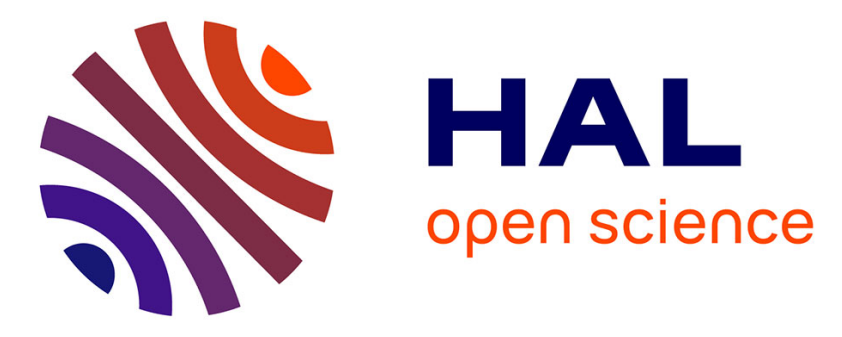

\title{
Urban green space classification and water consumption analysis with remote-sensing technology: a case study in Beijing, China
}

Suchuang Di, Zhao-Liang Li, Ronglin Tang, Xingyao Pan, Honglu Liu, Yong Niu

\section{- To cite this version:}

Suchuang Di, Zhao-Liang Li, Ronglin Tang, Xingyao Pan, Honglu Liu, et al.. Urban green space classification and water consumption analysis with remote-sensing technology: a case study in Beijing, China. International Journal of Remote Sensing, 2019, Fifth International Symposium on Recent Advances in Quantitative Remote Sensing (RAQRS), 40 (5-6), pp.1909-1929. 10.1080/01431161.2018.1479798 . hal-02377681

\section{HAL Id: hal-02377681 \\ https://hal.science/hal-02377681}

Submitted on 8 Dec 2020

HAL is a multi-disciplinary open access archive for the deposit and dissemination of scientific research documents, whether they are published or not. The documents may come from teaching and research institutions in France or abroad, or from public or private research centers.
L'archive ouverte pluridisciplinaire HAL, est destinée au dépôt et à la diffusion de documents scientifiques de niveau recherche, publiés ou non, émanant des établissements d'enseignement et de recherche français ou étrangers, des laboratoires publics ou privés. 


\section{Urban Green Land Classification and Water Consumption Analysis with Remote Sensing Technology ---a Case Study within the Northwest Region of Beijing City ${ }^{1}$}

Di Suchuang ${ }^{1,5}$, Li Zhao-liang ${ }^{2,3,4^{*}}$, Tang Ronglin ${ }^{2}$, Pan Xingyao ${ }^{1,5}$, Liu Honglu ${ }^{1,5}$, Yong Niu ${ }^{6}$

1. Beijing Water Science and Technology Institute, Beijing, 100048;

2. Institute of Geographic Sciences and Natural Resources Research, Beijing, 100101;

3. ICube, UdS, CNRS; 300 Bld Sebastien Brant, CS 10413, 67412 Illkirch, France;

4. Key Laboratory of Agri-informatics, Ministry of Agriculture Institute of Agricultural Resources and Regional Planning, Chinese Academy of Agricultural Sciences, Beijing, 100081;

5. Bejing Engineering Research Center for Non-conventional Water Resources Utilization and Water Saving, Beijng, 100048;

6. College of Forestry, Shandong Agricultural University, Taian, 271018

\section{Abstract:}

The green land water consumption on large region was difficult to be attained through traditional methods and a practical method was developed by using different sources of remote sensing data. Four major procedures were included as follows: (1) Green land area was derived from the high-spatial resolution Rapid Eye imagine by using Stratified Classification method. (2) Main green land vegetation types were identified by using Object-oriented Classification method. (3) Regional green land ET was inversed based on multi-temporal Landsat8 imagines by using Surface Energy Balance Algorithm for Land (SEBAL) model. (4) Water consumption patterns for different vegetation were analyzed and regional water consumption was estimated. The case study was carried out in the Northwest region of Beijing City and with the area of $147.5 \mathrm{~km}^{2}$. The green land area was $56.87 \mathrm{~km}^{2}$ and the deciduous broad-leaved forest area was the largest among 6 vegetation types. The total water consumption quantity for the green land in studying region in the growing period was $41.52 \mathrm{Mm}^{3}$. The quantity of water consumed for different vegetation types from high to low were deciduous broad-leaved forest, mixed green space, grass land, needle-leaved evergreen forest, golf course, the aquatic vegetation and the values were $17.43 \mathrm{Mm}^{3}, 13.52 \mathrm{Mm}^{3}, 4.74 \mathrm{Mm}^{3}, 3.81 \mathrm{Mm}^{3}, 1.24 \mathrm{Mm}^{3}, 0.79 \mathrm{Mm}^{3}$, respectively. These results were helpful for identifying vegetation types, monitoring

*Corresponding author. Email: lizhaoliang@ caas.cn 
vegetation growing status, managing green land and optimizing green land ecological function in Beijing region.

Key Words: Urban Green Land; Remote Sensing; Evapotranspiration (ET); Water Consumption; Surface Energy Balance Algorithm for Land (SEBAL)

\section{Introduction}

Urban green land is one of the important components for ecological and livable civic environment. The ecological functions of the urban green land are as following: absorbing carbon dioxide, releasing oxygen, mitigating Urban Heat Island (UHI) effects, enhancing air humidity, conserving water and soil, attenuating noise, annihilating airborne bacteria, reducing wind speed and dust in the air, as well as providing entertainment places for the citizens. Accounting for these advantages, lots of effects were made by local governments to enlarge green land area to attain better ecological effects in China. As the green land region enlarged, more and more water resource was consumed by the green land vegetation. Taking the Beijing City as an example, the total urban green land area is about $670 \mathrm{~km}^{2}$ and the quantity of the water used for ecological environment is about 0.59 billion $\mathrm{m}^{3}$. This amount occupied $16 \%$ of total water consumption in 2013(Statistical Bureau of Beijing City, 2013). Therefore, in the arid and semiarid regions, the ecological benefits and water consumption should be balanced and the studies on the water requirement for the different green land vegetation types were essential to develop ecological green land as well as to raise water resource efficiency.

Traditional methods to estimate water consumption included Lysimeter measurements, sap flow measurements, eddy covariance measurements, bowen ratio energy balance system, as well as water balance measurements. Some case studies were as follows: Cheng et al. (2002) used lysimeters to measure lawn water consumption in Beijing. Meng et al. (2005) utilized the Li-1600 steady state porometer to study the diurnal change trends of transpiration rate for 3 urban landscape trees. Wei et al. (1998) used bowen ratio energy balance methods to estimate the Water consumption by black locust and Chinese pine. Ma et al. (2006) 
utilized the Thermal Dissipation Sapwood Flow Velocity Probe (TDSFVP) and auto-meteorological stations to study the sap flow fluctuation patterns of different plots in Miao-fengshan area of Beijing. The results of these methods were accurate, but these point-scale-based methods were not suitable for estimating regional water consumption, particularly for heterogeneous urban green land which was usually composed by different types of vegetation. Besides, these methods were time-consuming, labor-intensive, and non-real-time.

However, with the rapid development of remote sensing technology, more data sources were available to retrieve regional parameters, such as vegetation types, surface temperature, vegetation indices, and energy components and these parameters were useful for enhancing the accuracy of regional water consumption estimations or evapotranspiration (ET) estimations. Many ET models had been developed to estimate regional ET based on remote sensing data (RS-ET models). These models included the Surface Energy Balance Algorithm for Land (SEBAL, Bastiaanssen, 1998; Tang et al., 2013), Surface Energy Balance System (SEBS, Su 2002), Surface Temperature - Vegetation Index space (Jiang and Islam, 2001, Tang et al.,2011) and Temporal Variations models ( $\mathrm{Lu}$ et al., 2013). The advantages for RS-ET models were as follows: (1) real-time and dynamically monitoring regional water consumption with lower cost; (2) clear physical significances and high accuracy. However, when these models were applied to estimate continuous regional ET on daily, weekly or monthly scale, disadvantages emerged ( $\mathrm{Li}$ et al. 2009). The limitations were as follows: (1) up scaling errors based instantaneous ET; (2) no thermal-infrared data under cloudy conditions.

To address these problems, a hybrid remotely sensed ET model (H-RS-ET) was developed (Cleugh et al., 2007, Mu et al., 2007, Mu et al., 2011) to produce global ET products (MOD16). The theoretical basis of the model was the Penman-Monteith (P-M) equation. The MOD16 products had a spatial resolution of $1 \mathrm{~km}$ and a temporal resolution of eight days, a month or a year and they were important as a global or regional ET reference. However, inaccuracies were found between the 
flux-tower-measured ET and the MOD16 products in different cases (Kim et al., 2012, Jia et al., 2012). The MOD16 ET products were not suitable for estimating the water consumption of urban green land which usually was scattered in the city region, because the spatial resolution of MOD16 was too coarse. Further, different green land vegetation types in urban green land might not be recognized from the MODIS product, therefore the information on water consumption differences among different spices was not attained. However, such information was important for water management and irrigation scheduling.

The objective of this paper is to develop a set of practical methods to estimate the quantity of water consumed by the urban green land by using different high spatial resolution and multi-temporal remote sensing data. The case study was carried out in the Northwest region of Beijing City. Firstly, green land area was derived from the high-spatial resolution Rapid Eye imagine by using Stratified Classification method. Secondly, the main green land vegetation types were identified by using Object-oriented Classification method. Thirdly, the regional green land ET was inversed based on multi-temporal Landsat8 imagines and meteorology data by using Surface Energy Balance Algorithm for Land (SEBAL) model. Fourthly, the water consumption patterns for different vegetation were analyzed and regional water consumption was estimated. In section 2 , we described the study area and data collections. In section 3, we introduced the classification methods, the SEBAL model as well as the regional water estimation method. In section 4, we presented the classification results, the regional daily ET spatial patterns, the comparison between the estimated ET values and measured ET values, as well as the regional total water consumption. In the last section, we provided the conclusions and several recommendations to improve the estimating accuracy.

\section{Study area and data}

\subsection{Study area}

Beijing, one of the largest cities in the world, covers approximately $16800 \mathrm{~km}^{2}$, with a population of 21 million people. It is the political, cultural and communication 
center of China and it has a history of more than 3000 years as a city and more than 800 years as a capital city. It is located between latitudes $39^{\circ} 26^{\prime} \mathrm{N}$ and $41^{\circ} 03^{\prime} \mathrm{N}$ and longitudes $115^{\circ} 25^{\prime} \mathrm{E}$ and $117^{\circ} 30^{\prime} \mathrm{E}$ (Fig.1.a). The south and east parts of Beijing is alluvial plain with the area of $6300 \mathrm{~km}^{2}$, while the north and west parts are hills and mountains with the area of $10500 \mathrm{~km}^{2}$ (Fig.1.b).The studying area focuses within the northwest part of central urban area and it is located between latitudes $39^{\circ} 57^{\prime} \mathrm{N}$ and $40^{\circ} 03^{\prime} \mathrm{N}$ and longitudes $116^{\circ} 15^{\prime} \mathrm{E}$ and $116^{\circ} 24^{\prime} \mathrm{E}$ (Fig.1.c) with the elevation of approximately $60 \mathrm{~m}$ above the mean sea level. The total area is about $147.5 \mathrm{~km}^{2}$ and main land covers included buildings, roads, water body, green land, bare soil (Fig.1.d) . The green land vegetation types included deciduous broad-leaved forest, evergreen needle-leaved forest, mixed green space, golf course, grass land, aquatic vegetation. The regions where green land are widely distributed include National Olympic Forest Park, Summer Palace, Yuanmingyuan Park, Bajia Park, Haidian Park, Betucheng Park. Besides, green lands are also widely distributed along the main roads and in the residential regions.
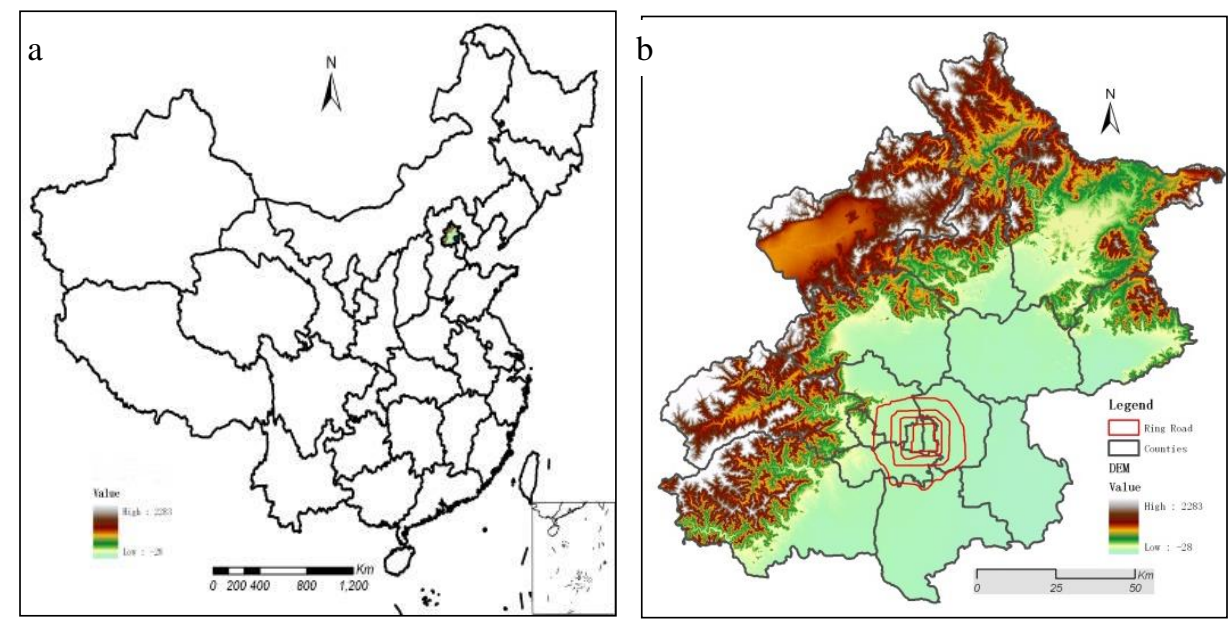

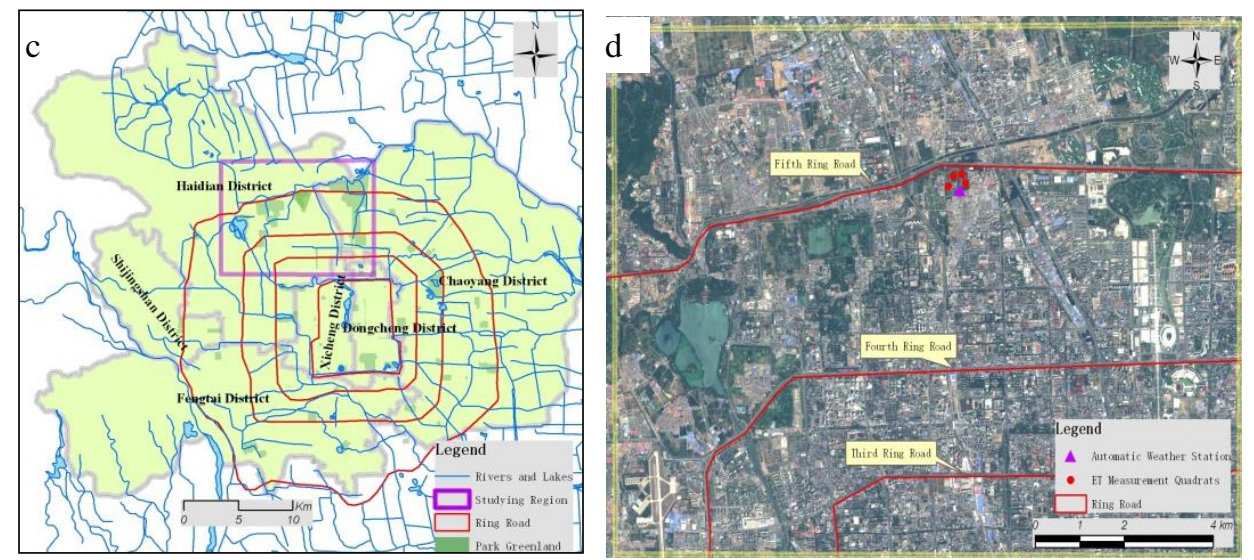

Fig.1 Location of the studying region and the weather station nearby (a. Bound of China, b. Bound of Beijing, c. Bound of studying region, d. the RapidEye imagine for studying region )

\subsection{Data collections and pre-processing}

Two types of multiple-spectral imagines used in the study included the RapidEye imagine and Landsat8 imagines. The RapidEye imagine was used to derive different land covers and to identify different green land vegetation types for the high spatial resolution $(5 \mathrm{~m})$ and it was combination of 5 bands (Blue, Green, Red, Red-edge, NIR). The RapidEye imagine was generated on Jun. 10 $0^{\text {th }}, 2009$ and they were provided by Eastdawn Company of Beijing, China.

Landsat8 imagines were used for inversing regional ET value for its multi-spectral bands. The multi-spectral datasets were acquired by both the Operational Land Imager (OLI) and by Thermal Infrared Sensor (TIRS). The OLI imagines consist of eight spectral bands with the spatial resolution of $30 \mathrm{~m}$ for bands 1 to 7 and band 9. The TIRS imagines consist of two spectral bands with the spatial resolution of $100 \mathrm{~m}$. Landsat8 images in four periods were used and they were generated on May $12^{\text {th }}$, Jun. $13^{\text {th }}$, Sep..$^{\text {st }}$ and Oct. $3^{\text {rd }}$ in 2013 . These Landsat8 imagines were downloaded from Earth Resources Observation and Science Center of United States Geological Survey (http://glovis.usgs.gov).

The pre-processing processes included radiance correction, geometric correction, calculating these parameters such as surface reflectance, surface albedo, Normalized Difference Vegetation Index (NDVI) and surface temperature. Details on the pre-processing procedures were provided in the work of Di et al (2012). 
Meteorology datasets were also used to inverse regional ET values and they were from the automatic weather station which was settled in the Bajia Park. These parameters such as air temperature, wind speed, solar radiance, relative humidity were measured every $5 \mathrm{~min}$.

To validate the ET inversion results, the water consumption experiments were carried out in the Bajia Park, and these parameters such as sap flow, soil water content, irrigation amount, precipitation were measured at four typical green land quadrats (Fig.1.d) from Apr. 29 $9^{\text {th }}$ to Oct. $25^{\text {th }}$ in 2013 . The water quantity consumed by the arbors was estimated by the sap flow measurement and the water quantity consumed by grass and the understory vegetation was estimated by the water balance method.

\section{Methodologies}

\subsection{Technology Roadmap}

The first step was to pre-process the remote sensing imagines and these procedures were included such as: radiance correction, geometric correction, calculating key parameters such as NDVI and surface temperature. The main research content might be divided into two parts: one was about land covers classification and vegetation identification and the other was about the multi- temporal regional ET reversion. The total regional consumption estimation was based on these above results.

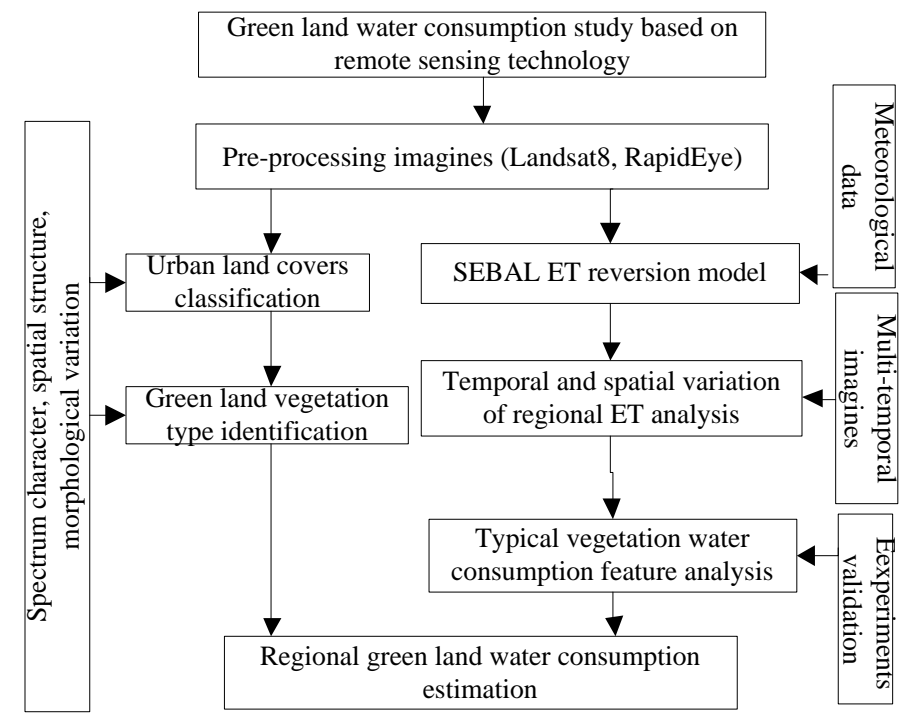

Fig. 2 Flow chart of green land water consumption study based on remote sensing technology

\subsection{Green land classification and typical vegetation identification}

\subsubsection{Urban Land Coverage Classification}


There were 4 major land cover types: water, green land, bare soil, and built-ups (including roads) in the study region and the spectral reflectance values in 5 bands of RapidEye imagine for the 4 land covers were shown in Fig.3. Water spectral reflectance values decreased from BLUE band to NIR band and water was of the minimum reflectance value in NIR band with the value of $7 \%$. Vegetation was of the minimum spectral reflectance value in RED band and the maximum value in NIR band. The Built-ups area has the minimum value in RE band and the maximum value in BLUE band, and bare soil has the minimum value in BLUE band and the maximum value in NIR band.

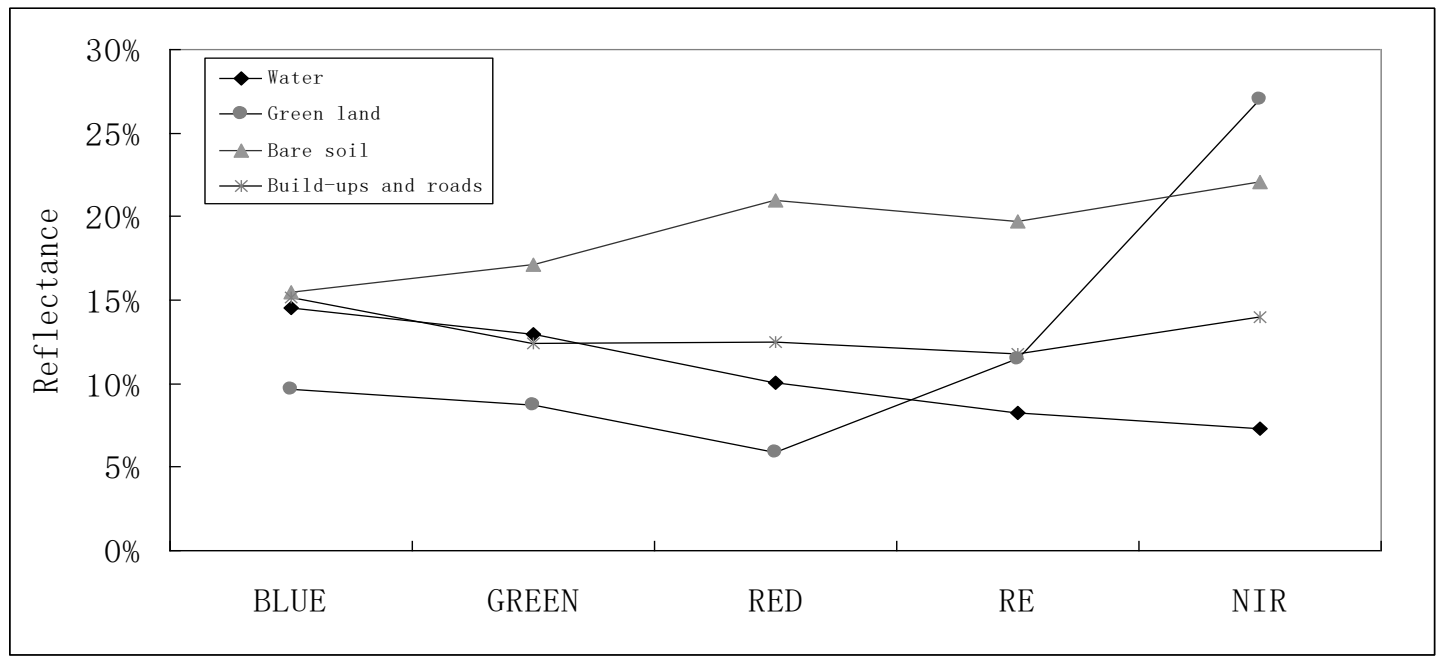

Fig. 3 Spectral reflectance values in 5 bands of the RapidEye imagine for 4 land covers

Stratified Classification method was used in the study and a decision tree was built, as shown in Fig.4. Water area and no water area could be partitioned according to NIR reflectance values, and the threshold value $12 \%$ was used. Vegetation area and no vegetation area could be partitioned by Normalized Difference Vegetation Index value (NDVI) which was derived from reflectance values of RED and NIR and threshold value 0.1 was used. For the similar spectral feature of bare soil and built-ups (including roads), they were hard to be distinguished only accounting for the spectral reflectance value and the spatial feature should be taken into account. The bare soil areas were distributed in outskirt of the city, while the built-ups were located in center of the city. 


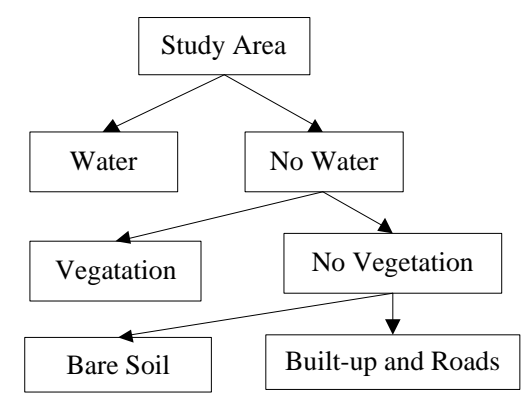

Fig. 4 Decision tree for stratified classification

\subsubsection{Vegetation type Identification}

The green land vegetation types included deciduous broad-leaved forest, needle-leaved evergreen forest, mixed green space, golf course, grass land, aquatic vegetation. The spectral features of these vegetations are similar and they would not be identified by using only spectral information. The object-oriented classification method was used and it would integrate the spectral information, the structural information as well as the morphological information in classification. Firstly, these imagines were segmented into a large number of units with similar features. Secondly, these units were classified by using supervised classification method and training samples.

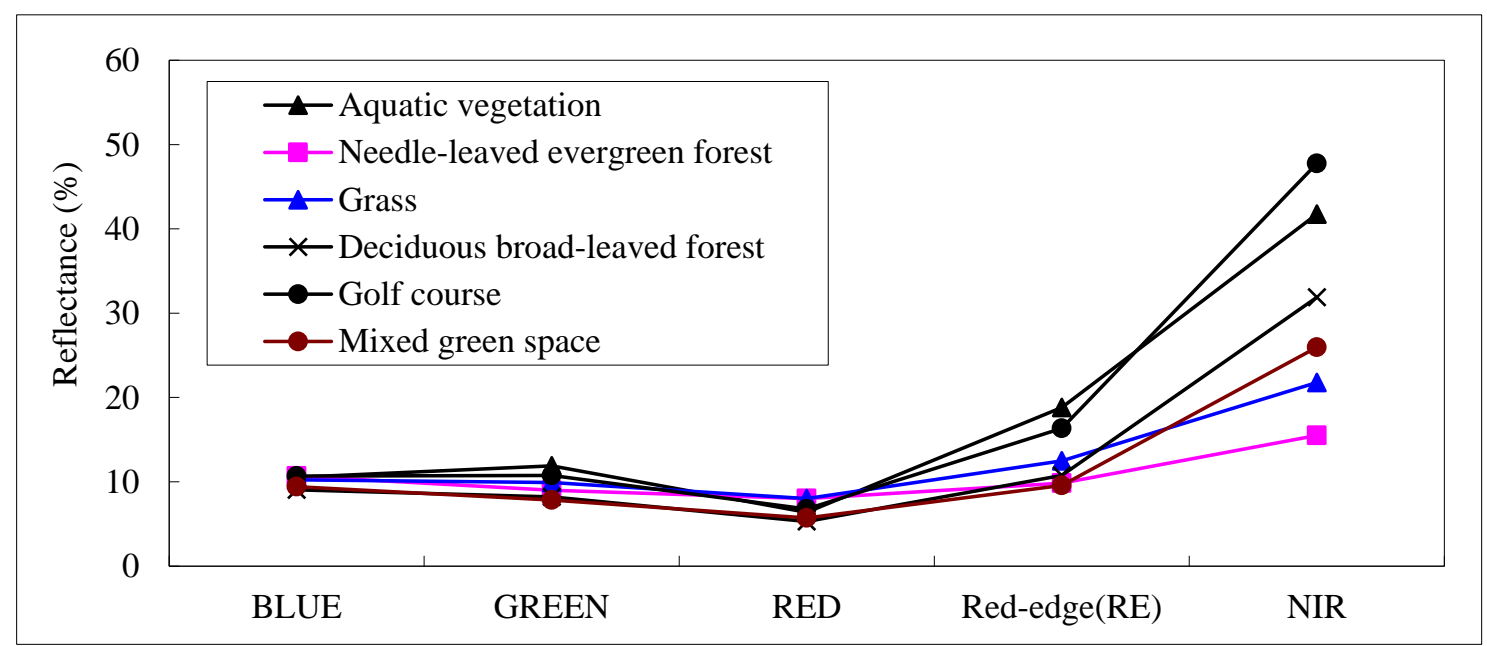

Fig.5 Spectral curve characteristics for different vegetation (based on RapidEye imagine) 


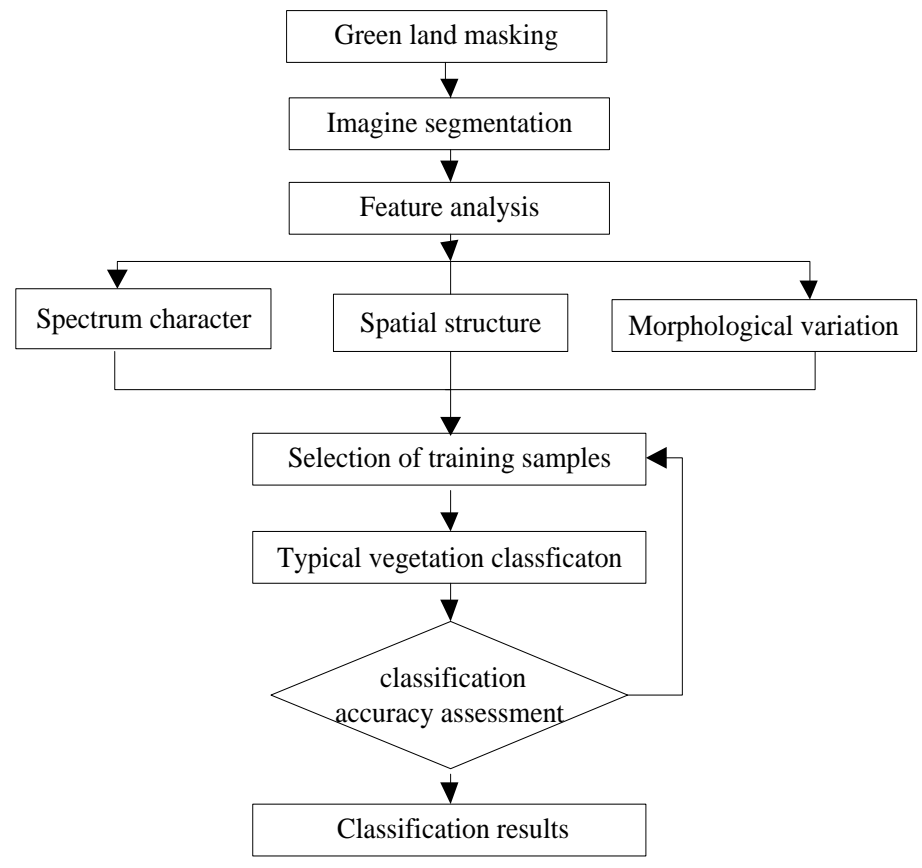

Fig. 6. Vegetation identification by Object-oriented classification method

\subsection{Regional ET reversing method}

The Surface Energy Balance Algorithm for Land (SEBAL) model has been widely used to inverse the land surface ET (Bastiaanseen, 2000, Pan and Liu, 2003, Qiao et al., 2007, Zeng et al., 2008) and it is based on physical surface energy balance theory as Eq.(3-1). In SEBAL model, the input data include visible band images, near infrared band imagines, thermal infrared band imagines, as well as meteorological data such as air temperature and weed speed. The output results include net surface solar radiation, soil heat flux, sensible heat flux and latent heat flux which is closely related with ET. The instantaneous ET is transformed to attain daily ET using the fixed ratio interpolation method (Zeng et al., 2008). The processes for SEBAL model were shown in Fig.7. 


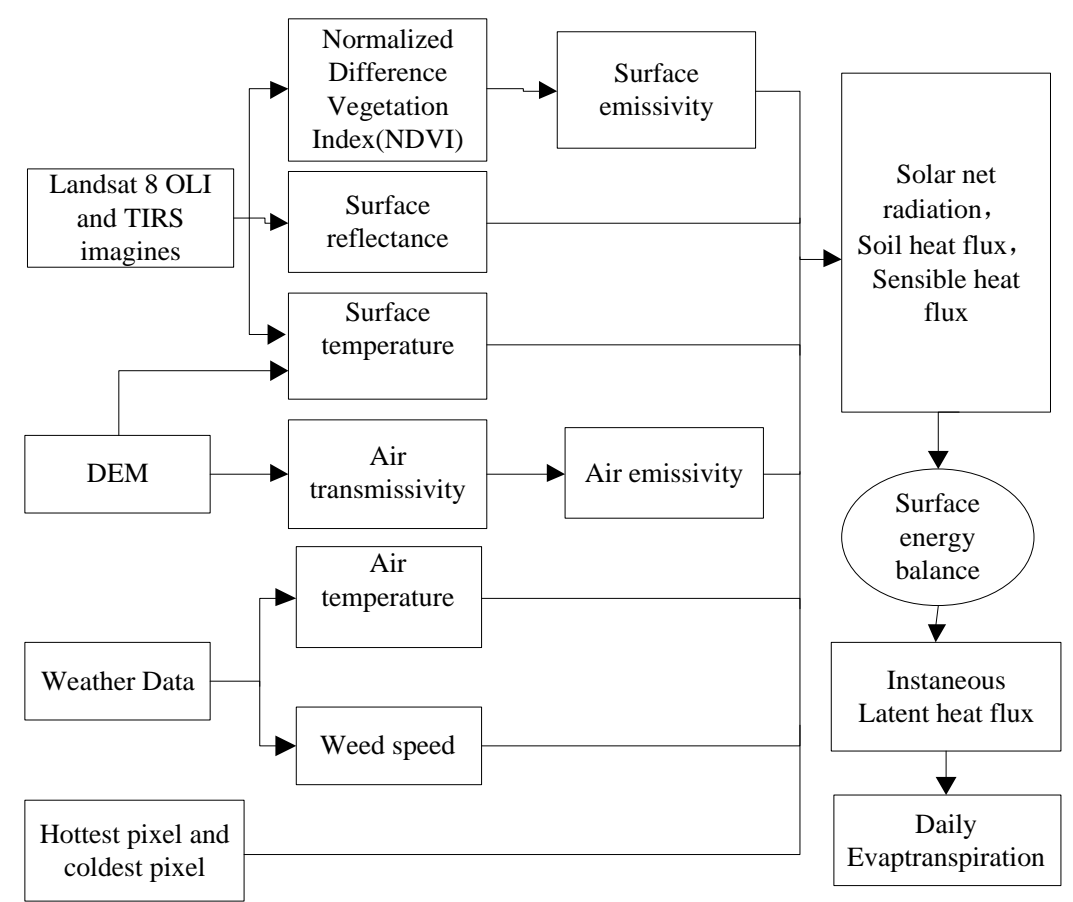

Fig.7 Flow chart for applying SEBAL model to inverse ET

$$
R_{n}+G+H+\lambda E T=0
$$

where $R_{\mathrm{n}}$ is instantaneous net radiation $\left(\mathrm{W} \cdot \mathrm{m}^{-2}\right), G$ is instantaneous soil heat

fluxes $\left(\mathrm{W} \cdot \mathrm{m}^{-2}\right), \mathrm{H}$ is instantaneous sensible heat exchange between air and land surface $\left(\mathrm{W} \cdot \mathrm{m}^{-2}\right), \lambda$ is latent heat of vaporization of water $\left(\mathrm{W} \cdot \mathrm{m}^{-2} \cdot \mathrm{mm}^{-1}\right)$, and $E T$ is instantaneous ET.

The net radiation estimation was based on the solar shortwave radiation, surface albedo, the atmospheric downward long-wave radiation, the surface upward long-wave radiation.

$$
\begin{aligned}
& R_{s \downarrow}=\frac{G_{x} \times \cos (\theta)}{d_{r}^{2}} \times \tau_{s w} \\
& R_{L \downarrow}=\varepsilon_{a} \sigma T_{a}^{4} \\
& R_{L \uparrow}=\varepsilon_{s} \sigma T_{s}^{4} \\
& R_{n}=(1-\alpha) R_{S \downarrow}+R_{L \downarrow}-R_{L \uparrow}-(1-\varepsilon) R_{L \downarrow}
\end{aligned}
$$


Where $R_{s \downarrow}$ is the solar shortwave radiation $\left(\mathrm{W} \cdot \mathrm{m}^{-2}\right), G_{x}$ is the solar constant which is $1367 \mathrm{~W} \cdot \mathrm{m}^{-2}, \theta$ is the solar zenith angle $(-), d_{r}$ is the normalization sun-earth distance (-), $\tau_{s w}$ is the Atmospheric one-way transmission rate (-), $R_{L \downarrow}$ is the atmospheric downward long-wave radiation $\left(\mathrm{W} \cdot \mathrm{m}^{-2}\right), \varepsilon a$ is the air emissivity $(-), \sigma$ is Stefan-Boltzmann constant which is $5.67 \times 10^{-8} \mathrm{~W} \cdot \mathrm{m}^{-2} \cdot \mathrm{K}^{-4}, T_{a}$, is the air temperature $(\mathrm{K}), R_{L \uparrow}$ is the surface upward long-wave radiation $\left(\mathrm{W} \cdot \mathrm{m}^{-2}\right), \varepsilon_{s}$ is the surface emissivity (-), $T_{s}$, is the surface temperature $(\mathrm{K}), a$ is surface albedo, (-).

The soil heat flux which was absorbed by the vegetation or soil was estimated according to the empirical equation.

$$
G=\frac{T_{s}-273.16}{\alpha} \times\left[0.0032 \times \frac{\alpha}{c_{11}}+0.0062 \times\left(\frac{\alpha}{c_{11}}\right)^{2}\right] \times\left(1-0.978 N D V I^{4}\right) \times R_{n}
$$

Where $c_{11}$ is a empirical parameter (-) which was determined by the satellite passing time. The values were $0.9,1.0$ and 1.1, respectively, for these periods such as before 12:00, during 12: 00 and 14:00, and after 14:00.

The sensible heat flux was estimated according to these parameters such as the aerodynamic resistance, the air temperature and the aerodynamic temperature and the recursion method was used. In SEBAL, there was an assumption that the difference value between the land aerodynamic temperature and the air temperature was linearly related with the surface temperature. The linear relationship would be determined by using two extreme pixels in the same remote sensing imagine. The wettest pixel was usually selected in the water body or high density vegetation region where the sensible flux is zero, while the driest pixel was usually selected in the sand region or bare dry farmland where the latent flux was zero. Details on the SEBAL model were provided in the work of Bastiaanssen et al.(1998)

Once the $R_{n}, G$ and $H$ were determined, the instant latent heat flux for every pixel was estimated by the energy balance equation.

$$
\lambda E T_{i n s}=R_{n}-G-H
$$

Where $E T_{\text {ins }}$ is the instantaneous ET $(\mathrm{mm} / \mathrm{s})$. 
For green land irrigation management, the daily or longer time scales are of great significance. However, the SEBAL model only providedthe snapshots of ET at the time of a satellite overpass. Therefore, the instantaneous regional ET should be up scaled to attain daily regional ET. Generally, there were four commonly used ET up-scaling schemes, namely, the constant evaporative fraction $(E F)$ method, the constant reference evaporative fraction $\left(E F_{r}\right)$ method, the constant extraterrestrial solar radiation ratio $\left(R_{p}\right)$ method, and the constant observed global solar radiation ratio $\left(R_{g}\right)$ method. Details on these methods were provided in the work of Tang et al. (2013). In this study the $E F$ method was used due to its simplification and high accuracy. There was an assumption that the instantaneous $E F$ at the time of the satellite overpass and the daily average $E F$ was the same.

$$
\begin{aligned}
& \Lambda_{\text {ins }}=\frac{R_{n}-G-H}{R_{n}-G}=\frac{\lambda E T_{i n s}}{R_{n}-G}=\Lambda_{24} \\
& E T_{24}=\frac{\left(R_{n 24}-G_{24}\right) \times \Lambda_{24} \times \beta}{\lambda} \approx \frac{R_{n 24} \times \Lambda_{24} \times \beta}{\lambda}
\end{aligned}
$$

where $\Lambda_{\text {ins }}$ and $\Lambda_{24}$ are instantaneous evaporative fraction (-) and average daily evaporative fraction (-), respectively. $R_{n 24}$ is the daily average radiation (W· $\left.\mathrm{m}^{-2}\right), G_{24}$ the daily average soil heat flux $\left(\mathrm{W} \cdot \mathrm{m}^{-2}\right)$ which is ignorable. $E T_{24}$ is the daily average $\mathrm{ET}(\mathrm{mm} / \mathrm{d}), \beta$ is the temporal scaling factor with the value of $86400(\mathrm{~s} / \mathrm{d})$.

\subsection{Green land water consumption estimation}

Four typical imagines in different growing seasons in 2013 were used to reverse regional daily ET. The results were validated with the water consumption experiments results. Further the spatial patterns of green land water consumption were analyzed.

Based on the vegetation classification results and the daily ET reversion results, the water consumption changing tends for typical vegetations were analyzed. The changing trends were interpolated on temporal scales from daily to monthly. Finally, the total quantity of water consumed by the green land was estimated according to the areas of different vegetation area and monthly average ET values.

\section{Results and discussion}

\subsection{Green land classification and typical vegetation identification}




\subsubsection{Urban land coverage classification results}

According the stratified classification results, the green land area was about $56.87 \mathrm{~km}^{2}$ accounting for $38.6 \%$ of total studying region. The areas for built-ups and roads, green land, water, bare soil were $84.30 \mathrm{~km}^{2}, 56.87 \mathrm{~km}^{2}, 3.79 \mathrm{~km}^{2}, 2.54 \mathrm{~km}^{2}$, respectively. To evaluate the accuracy of the stratified classification results, 100 random sampling points were generalized and the classification results were compared with the investigation results. The total accuracy was $94 \%$.

Tab.1 Statistics results for different land covers derived from stratified classification

\begin{tabular}{ccccc}
\hline Index & Land covers & Pixel number & Area $\left(\mathrm{km}^{2}\right)$ & Percentage \\
\hline 1 & Water & 151553 & 3.79 & $2.6 \%$ \\
2 & Green land & 2274649 & 56.87 & $38.6 \%$ \\
3 & Bare soil & 101764 & 2.54 & $1.7 \%$ \\
4 & Built-ups and roads & 3372173 & 84.30 & $57.2 \%$ \\
& Sum & 5900139 & 147.50 & $100.0 \%$ \\
\hline
\end{tabular}

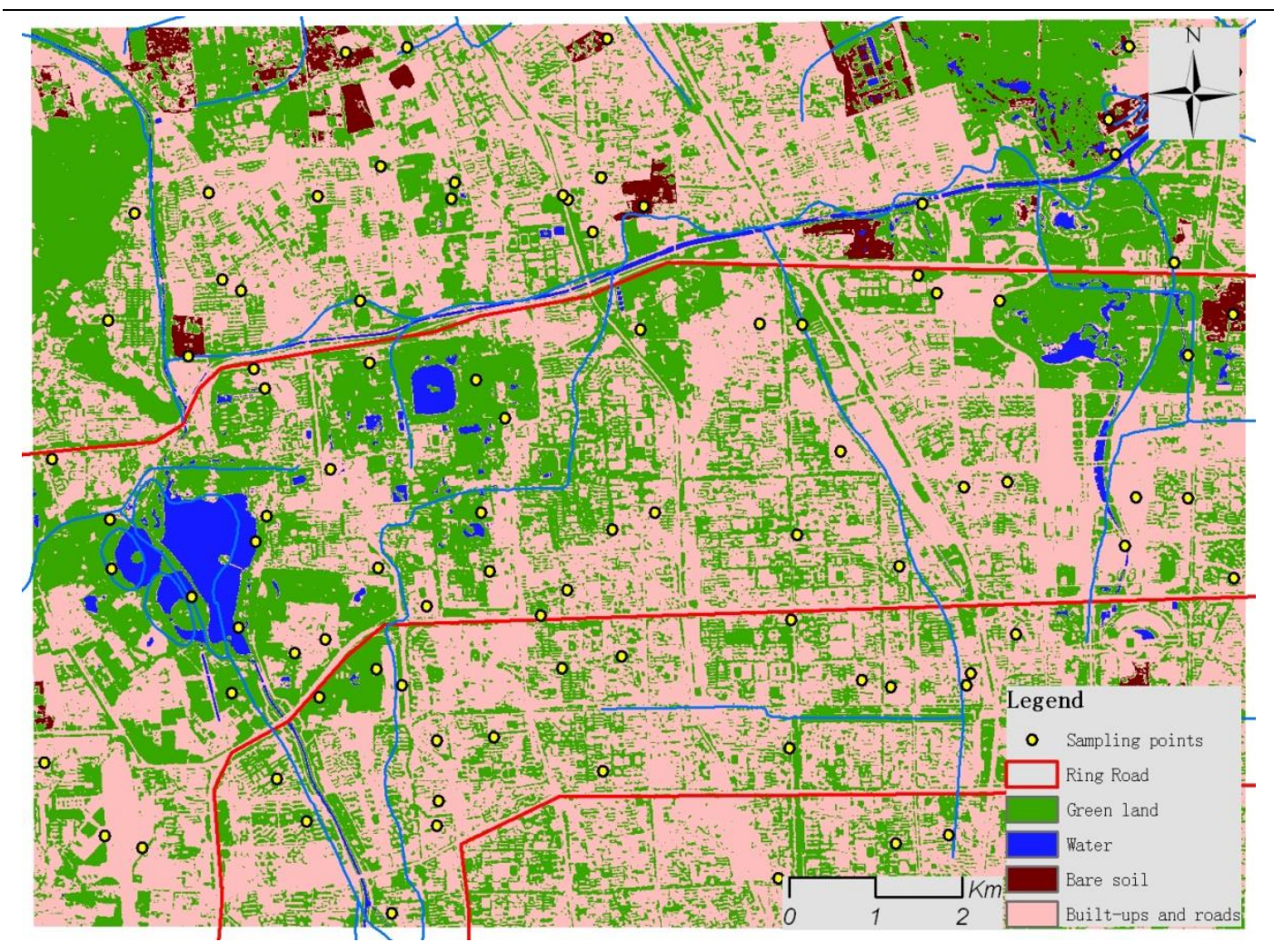

Fig.8 Classification results for different land cover types based on the RapidEye imagines

\subsubsection{Vegetation type identification results}

According to the object-oriented classification results, the deciduous broad-leaved forest area was the maximum in green land region and its value was $23.24 \mathrm{~km}^{2}$ which was accounting for $40.9 \%$ of total green land region and $15.8 \%$ of 
studying region. The areas for the needle-leaved evergreen forest, the aquatic vegetation, the grass land, the golf course, and the mixed green space, were $5.31 \mathrm{~km}^{2}$, $0.82 \mathrm{~km}^{2}, 8.63 \mathrm{~km}^{2}, 1.45 \mathrm{~km}^{2}$, and $17.42 \mathrm{~km}^{2}$, respectively.

Tab.2 Statistics results for different vegetation types derived from object-oriented classification

\begin{tabular}{|c|c|c|c|c|}
\hline Index & Vegetation type & Area $\left(\mathrm{km}^{2}\right)$ & $\begin{array}{l}\text { Percentage of } \\
\text { green land }\end{array}$ & $\begin{array}{c}\text { Percentage of } \\
\text { studying region }\end{array}$ \\
\hline 1 & $\begin{array}{c}\text { Deciduous } \\
\text { broad-leaved forest }\end{array}$ & 23.24 & $40.9 \%$ & $15.8 \%$ \\
\hline 2 & $\begin{array}{l}\text { Needle-leaved } \\
\text { evergreen forest }\end{array}$ & 5.31 & $9.3 \%$ & $3.6 \%$ \\
\hline 3 & Aquatic vegetation & 0.82 & $1.4 \%$ & $0.6 \%$ \\
\hline 4 & Grass land & 8.63 & $15.2 \%$ & $5.8 \%$ \\
\hline 5 & Golf course & 1.45 & $2.5 \%$ & $1.0 \%$ \\
\hline \multirow[t]{2}{*}{6} & Mixed green space & 17.42 & $30.6 \%$ & $11.8 \%$ \\
\hline & Sum & 56.87 & $100.0 \%$ & $38.6 \%$ \\
\hline
\end{tabular}

To evaluate the accuracy of the object-oriented classification results, 100 random sampling points were generalized in the green land region and the vegetation types identification results were compared with the investigation results. The total accuracy is $78 \%$. Some low density forests (broad leaved or needle-leaved) were misclassified as grass land and some high density forests were misclassified as mixed green space. The uncertainties resulted from the variations in density, the heterogeneity of vegetation structure, growing status as well as difference of the soil moisture. 


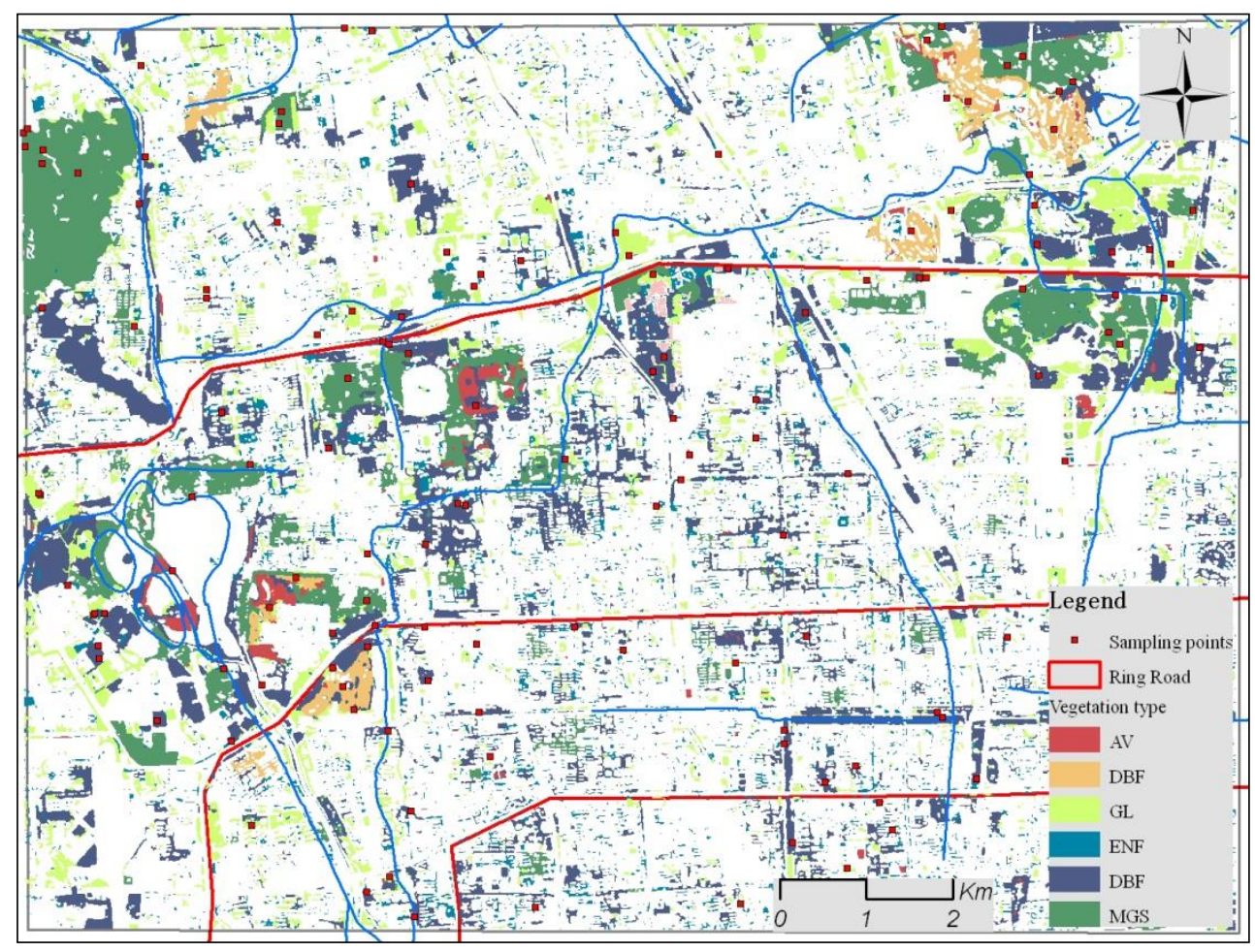

Fig.9 Classification results for different vegetation types based on the RapidEye imagine

\subsection{Regional ET reversion results}

\subsubsection{Spatial distribution of regional ET in different seasons.}

The regional daily ET values were reversed by using SEBAL model on 4 typical days (May 12 $2^{\text {th }}$, Jun. $13^{\text {th }}$, Sep. $1^{\text {st }}$ and Oct. $3^{\text {rd }}$ in 2013) and the regional ET spatial distribution patterns were shown as Fig.10 13.

Firstly, the ET values for different land covers were analyzed based on the revered daily regional ET maps. The average daily ET values for different land covers from high to low were water body, high density vegetation areas, low density vegetation areas, none vegetation areas such as built-ups and roads. The urban water body consumed much more water than other land covers per unit area and the daily average ET values ranged from 6.1 to $10.0 \mathrm{~mm}$. Theses urban water bodies were located in the regions sunch as Kunming Lake, Fuhai Lake, Olymipic Lake, Qinghe River and Kunyu River. The daily average ET values for high density vegetation areas ranged from 4.1 to $6.0 \mathrm{~mm}$ and these areas were located in these parks such as National Olympic Forest Park, Summer Palace, Yuanmingyuan Park, Bajia Park, Haidian Park, Betucheng Park. The daily average ET values for low density vegetation areas ranged from 2.1 to $4.0 \mathrm{~mm}$ and these low density vegetation areas 
were located along the roadside, in the residential area as well as in the parks. The daily ET values for most built-ups, road areas, and bare soils ranged from 0 to $2.0 \mathrm{~mm}$. these none vegetation areas were mainly located in the southern and eastern parts of the studying area.

Secondly, the spatial distribution patterns of regional daily ET were analyzed. The average ET values in the northern region were higher than the values in the southern region. The ET values within the $4^{\text {th }}$ Ring Road were much lower than other regions, because land covers in this region were mainly high density built-ups and roads, while the green lands were much sparse than other regions. The ET values within the region between $5^{\text {th }}$ Ring road and $4^{\text {th }}$ Ring road were much higher than other regions because of more green land and water bodies.

Further, the temporal variations of the daily ET maps on 4 typical days were analyzed, and the days on which the mean regional ET values ranked from high to low were Sep. $1^{\text {st }}$, followed by May $12^{\text {th }}$, Oct. $3^{\text {rd }}$ and Jun. $13^{\text {th }}$. Under clear sky condition, the strongest solar radiation usually appears in late June, and the highest air temperature usually appears in July in Beijing region, therefore the ET values should be higher in this period than other periods. However, in this study, when the Landsat8 imagines were generated, there were some thin clouds over the studying area. On one hand the net radiation were reduced and on the other hand the air humidity was increased so the ET values on Jun. $13^{\text {th }}$ were lower than other days. 


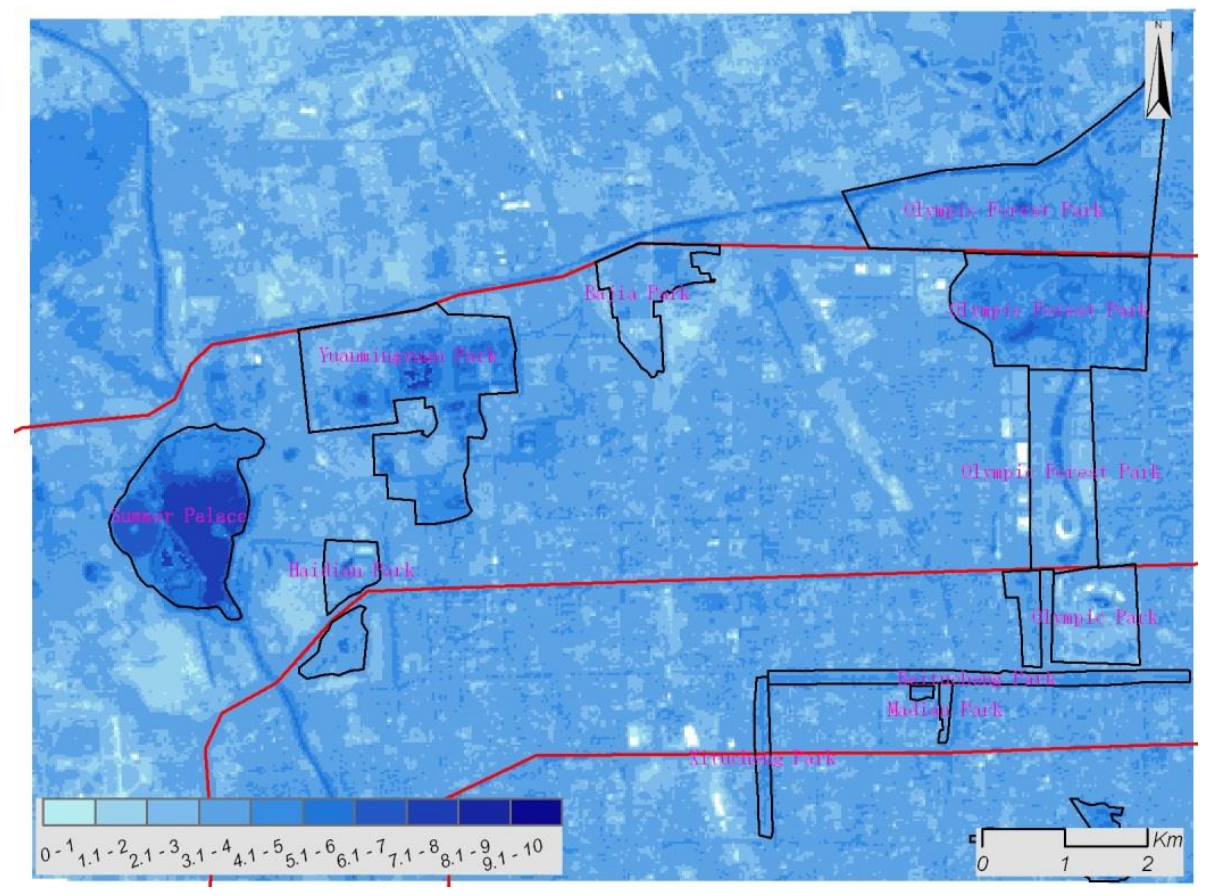

Fig.10 Reversed regional ET map based on SEBAL on May $12^{\text {th }}, 2013$

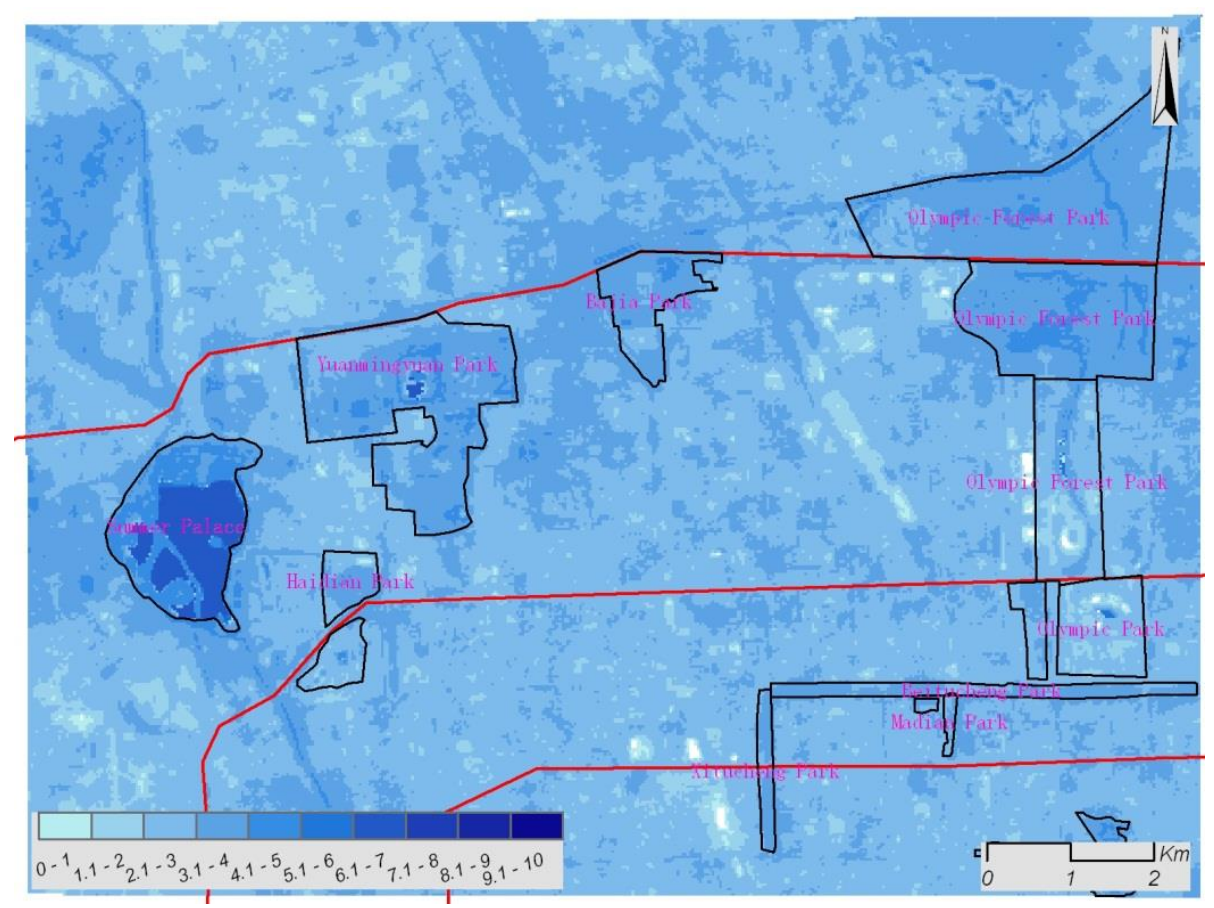

Fig.11 Reversed regional ET map based on SEBAL on Jun. $13^{\text {th }}$, 2013 


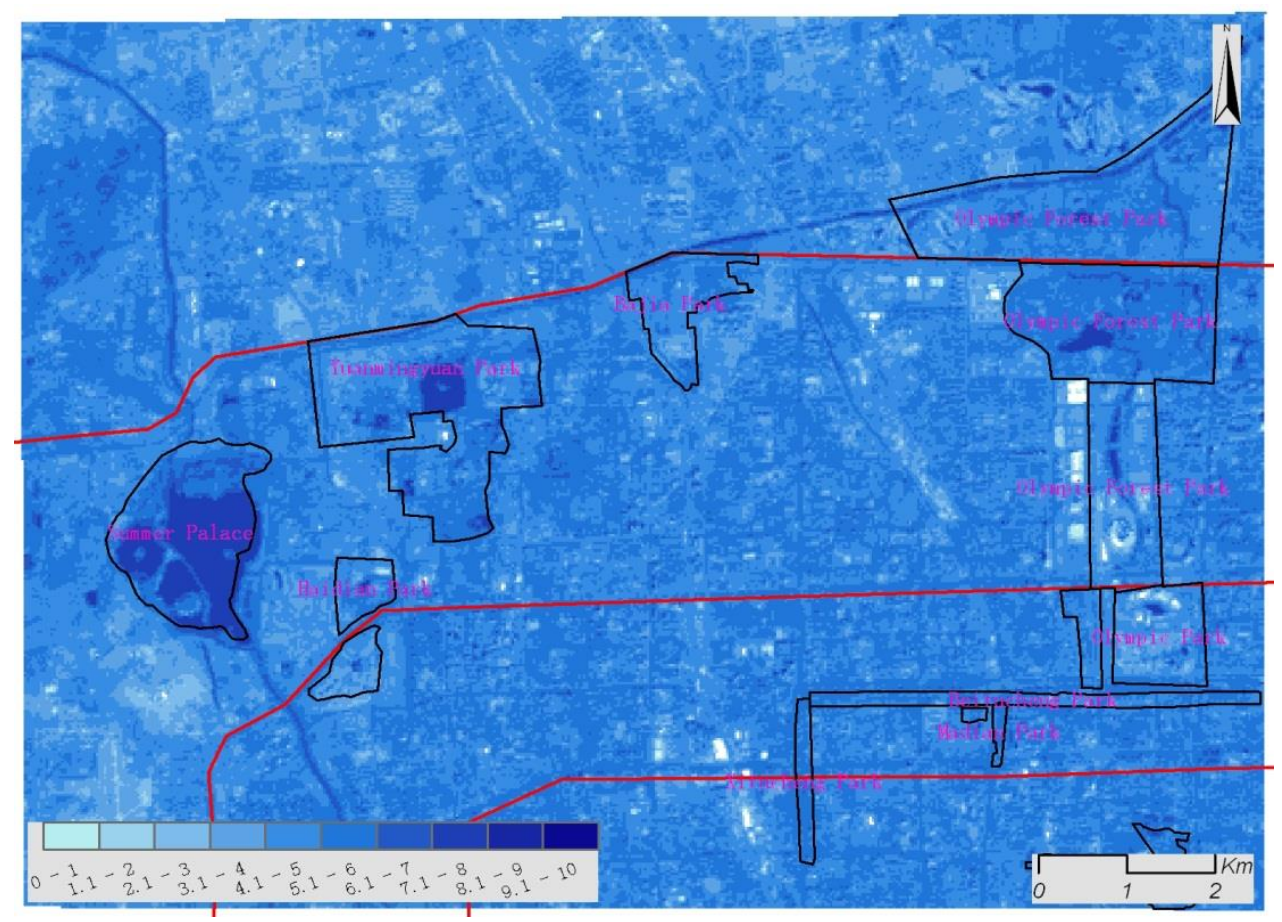

Fig.12 Reversed regional ET map based on SEBAL on Sep. $1^{\text {st }}, 2013$

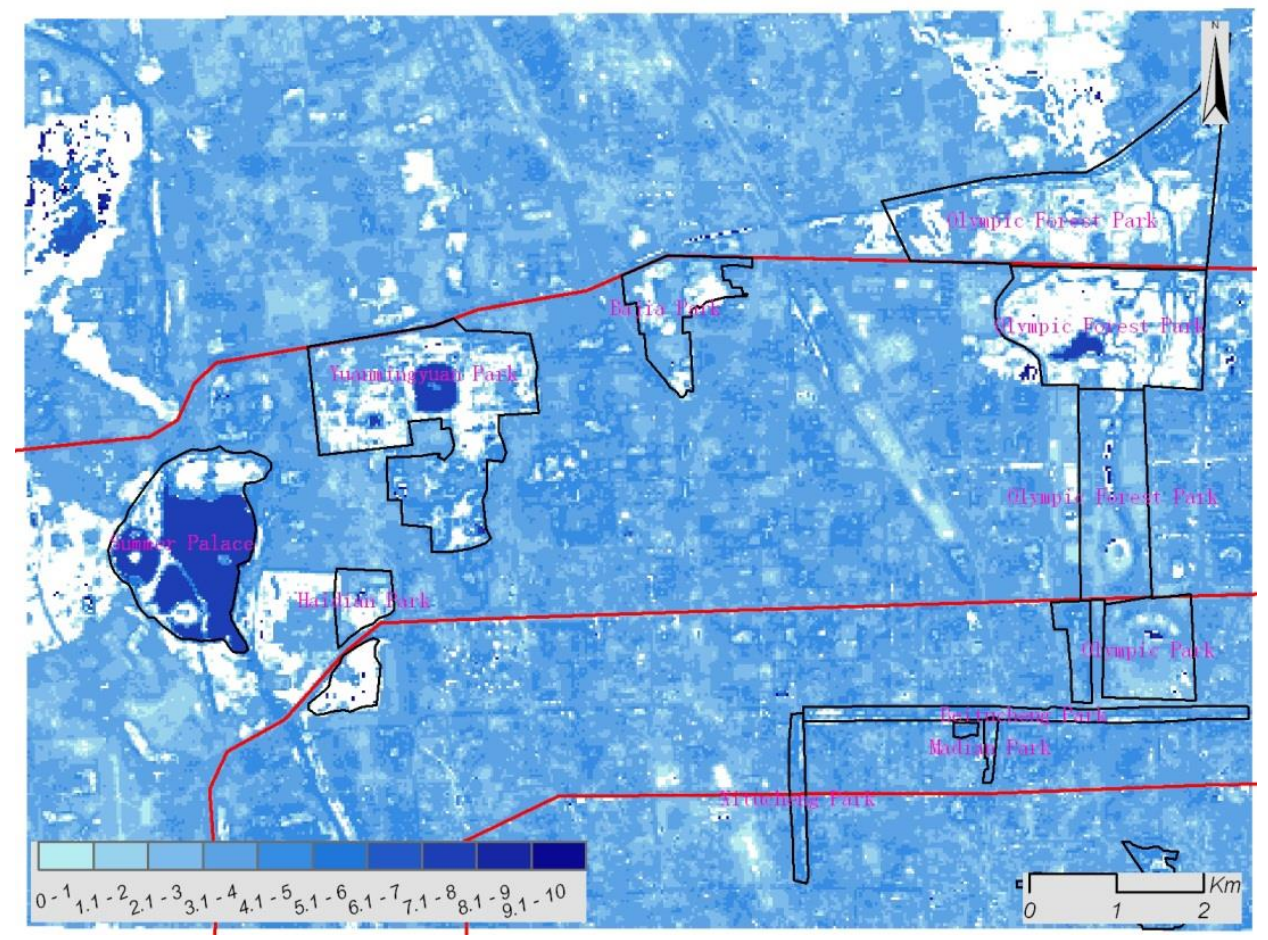

Fig.13 Reversed regional ET map based on SEBAL on Oct. $3^{\text {rd }}, 2013$

\subsubsection{Comparison of reversed and measured ET values for typical quadrats}

The reversed ET values on typical days were extracted from the ET maps and the measured ET values were from sap flow measurements or from water balance measurement. Four quadrets were selected in Bajia Park and the vegetation types 
included Populus, Salix babylonica, sabina chinensis, Ophiopogon japonicus, Poa аппиа. The differences between the reversed and the measured ET values ranged from -2.0 to $2.5 \mathrm{~mm} / \mathrm{d}$, and the mean value is $0.1 \mathrm{~mm} / \mathrm{d}$.

The relative errors ranged from $-33.9 \%$ to $94.3 \%$, and the mean relative error was $7.9 \%$. The determine coefficient of determination was 0.1392 . The errors were mainly caused by mixed pixels and the detailed information on green land was generalized due to the coarse spatial resolution of OLI and TIRS sensors.

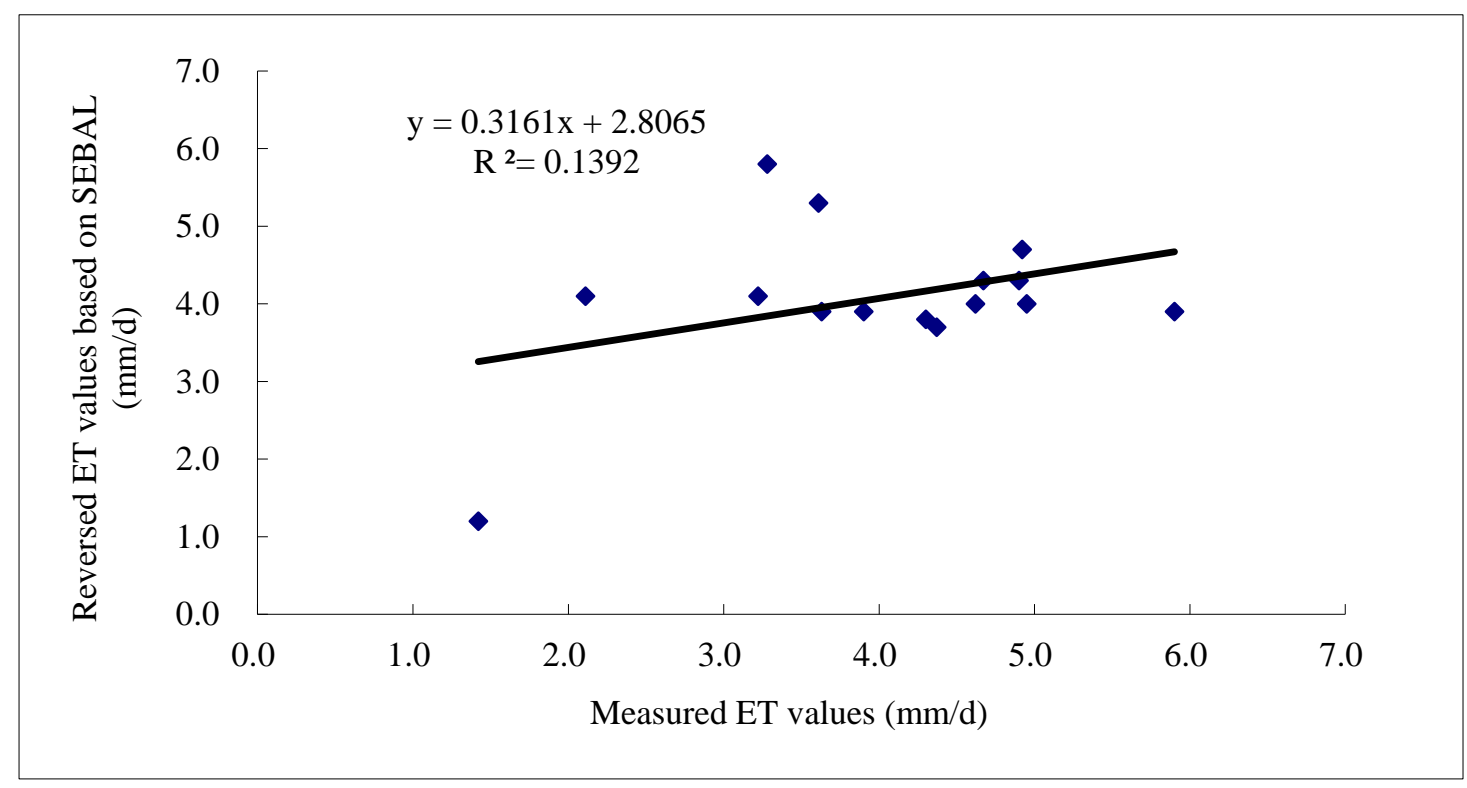

Fig. 14 Comparison between measured ET values and reversed ET values

Tab. 3 Comparison between measured and reversed ET values

\begin{tabular}{|c|c|c|c|c|c|}
\hline Date & $\begin{array}{l}\text { Vegetation } \\
\text { type }\end{array}$ & $\begin{array}{c}\text { Reversed } \\
\text { daily ET } \\
(\mathrm{mm} / \mathrm{d})\end{array}$ & $\begin{array}{c}\text { Measured } \\
\text { daily ET } \\
(\mathrm{mm} / \mathrm{d})\end{array}$ & $\begin{array}{c}\text { Absolute Error } \\
\qquad(\mathrm{mm} / \mathrm{d})\end{array}$ & Relative Error \\
\hline \multirow{4}{*}{ May $12^{\text {th }}$} & Populu & 4.3 & 4.9 & -0.6 & $-12.2 \%$ \\
\hline & $\begin{array}{l}\text { Sabina chinensis, } \\
\text { Ophiopogon japonicus }\end{array}$ & 3.9 & 3.6 & 0.3 & $7.4 \%$ \\
\hline & Salix babylonica & 3.8 & 4.3 & -0.5 & $-11.6 \%$ \\
\hline & $\begin{array}{l}\text { Sabina chinensis, } \\
\text { Poa annua }\end{array}$ & 4 & 5 & -1.0 & $-19.2 \%$ \\
\hline \multirow{4}{*}{ Jun. $13^{\text {th }}$} & Populu & 3.9 & 3.9 & 0.0 & $0.0 \%$ \\
\hline & $\begin{array}{l}\text { Sabina chinensis, } \\
\text { Ophiopogon japonicus }\end{array}$ & 3.9 & 5.9 & -2.0 & $-33.9 \%$ \\
\hline & Salix babylonica & 3.7 & 4.4 & -0.7 & $-15.3 \%$ \\
\hline & $\begin{array}{l}\text { Sabina chinensis, } \\
\text { Роа аппиа }\end{array}$ & 4 & 4.6 & -0.6 & $-13.4 \%$ \\
\hline Sep. $1^{\text {st }}$ & Populu & 4.7 & 4.9 & -0.2 & $-4.5 \%$ \\
\hline
\end{tabular}




\begin{tabular}{|c|c|c|c|c|c|}
\hline Date & $\begin{array}{l}\text { Vegetation } \\
\text { type }\end{array}$ & $\begin{array}{r}\text { Reversed } \\
\text { daily ET } \\
(\mathrm{mm} / \mathrm{d})\end{array}$ & $\begin{array}{c}\text { Measured } \\
\text { daily ET } \\
(\mathrm{mm} / \mathrm{d})\end{array}$ & $\begin{array}{l}\text { Absolute Error } \\
\qquad(\mathrm{mm} / \mathrm{d})\end{array}$ & Relative Error \\
\hline & $\begin{array}{l}\text { Sabina chinensis, } \\
\text { Ophiopogon japonicus }\end{array}$ & 5.8 & 3.3 & 2.5 & $76.8 \%$ \\
\hline & Salix babylonica & 4.1 & 3.2 & 0.9 & $27.3 \%$ \\
\hline & $\begin{array}{l}\text { Sabina chinensis, } \\
\text { Poa аппиа }\end{array}$ & 5.3 & 3.6 & 1.7 & $46.8 \%$ \\
\hline \multirow{4}{*}{ Oct. $3^{\text {rd }}$} & Populu & - & - & - & - \\
\hline & $\begin{array}{l}\text { Sabina chinensis, } \\
\text { Ophiopogon japonicus }\end{array}$ & 4.3 & 4.7 & -0.4 & $-7.9 \%$ \\
\hline & Salix babylonica & 4.1 & 2.1 & 2.0 & $94.3 \%$ \\
\hline & $\begin{array}{l}\text { Sabina chinensis, } \\
\text { Pоа аппиа }\end{array}$ & 1.2 & 1.4 & -0.2 & $-15.5 \%$ \\
\hline Average & ---- & 4.1 & 4 & 0.1 & $7.9 \%$ \\
\hline
\end{tabular}

\subsection{Water-consuming patterns for different vegetation and regional water consumption quantity}

\subsubsection{Water-consuming patterns for different vegetation}

Base on the vegetation type classification map and the reversed daily ET maps, the variation curves of seasonal water consumption might be generated by selecting typical sample points and by extracting the ET values on typical days. 14 sampling points were selected and the details were provided in Tab.4.

The ET values from water bodies sampling points were much higher than green land area and they ranged from $6.2 \mathrm{~mm} / \mathrm{d}$ to $7.9 \mathrm{~mm} / \mathrm{d}$. The mean ET value for water bodies was $7.2 \mathrm{~mm} / \mathrm{d}$. The average daily ET values for different vegetation from high to low were aquatic vegetation, golf course, mixed green space, deciduous broad-leaved forest, needle-leaved evergreen forest, grass land and the average daily ET values were $5.3 \mathrm{~mm} / \mathrm{d}, 4.7 \mathrm{~mm} / \mathrm{d}, 4.3 \mathrm{~mm} / \mathrm{d}, 4.1 \mathrm{~mm} / \mathrm{d}, 3.9 \mathrm{~mm} / \mathrm{d}, 3.0 \mathrm{~mm} / \mathrm{d}$, respectively.

According to the sampling points, the average ET values for different vegetation types and water bodies were shown in Fig.15.

The changing trends of seasonal ET curves for different vegetation types and water body were similar and they were like a group of sine lines. The highest ET values appeared on Sep. $1^{\text {st }}$ and the lowest ET values appeared on Jun. $13^{\text {th }}$. The curve of deciduous broad-leaved forest crossed the curve of mixed green space and the curve of needle-leaved evergreen forest, because the ET values for these vegetation types in some periods were similar. 
Tab. 4 Sampling points information and reversed ET values

\begin{tabular}{|c|c|c|c|c|c|c|c|c|}
\hline \multirow{2}{*}{ ID } & \multirow{2}{*}{ Sampling points } & \multirow{2}{*}{ Vegetation type } & \multicolumn{2}{|c|}{ Geographic coordinate } & \multicolumn{2}{|c|}{ Reversed ET } & \multicolumn{2}{|c|}{$(\mathbf{m m} / \mathbf{d})$} \\
\hline & & & longitude & latitude & 12-May & 13-Jun. & 1-Sep. & 3-Oct. \\
\hline 1 & $\begin{array}{l}\text { Lotus pond in } \\
\text { Yuanmingyuan } \\
\text { Park }\end{array}$ & aquatic vegetation & $116.303^{\circ} \mathrm{E}$ & $40.008^{\circ} \mathrm{N}$ & 5.6 & 4.1 & 5.5 & 4.9 \\
\hline 2 & $\begin{array}{l}\text { Lotus pond in } \\
\text { Summer Palace }\end{array}$ & aquatic vegetation & $116.264^{\circ} \mathrm{E}$ & $39.983^{\circ} \mathrm{N}$ & 5.9 & 4.6 & 6.5 & 4.8 \\
\hline 3 & $\begin{array}{l}\text { Northern part of } \\
\text { Kunming Lake }\end{array}$ & water body & $116.266^{\circ} \mathrm{E}$ & $39.993^{\circ} \mathrm{N}$ & 7.2 & 6.3 & 7.8 & 7.4 \\
\hline 4 & $\begin{array}{l}\text { Southern part of } \\
\text { Kunming Lake }\end{array}$ & water body & $116.27^{\circ} \mathrm{E}$ & $39.987^{\circ} \mathrm{N}$ & 7.1 & 6.2 & 7.9 & 7.4 \\
\hline 5 & $\begin{array}{l}\text { Lawn in Olympic } \\
\text { Park }\end{array}$ & grass land & $116.386^{\circ} \mathrm{E}$ & $40.012^{\circ} \mathrm{N}$ & 4 & 3.4 & 4 & 3.4 \\
\hline 6 & $\begin{array}{l}\text { Lawn in Peking } \\
\text { University }\end{array}$ & grass land & $116.297^{\circ} \mathrm{E}$ & $39.987^{\circ} \mathrm{N}$ & 2.4 & 1.3 & 3.3 & 2 \\
\hline 7 & $\begin{array}{l}\text { Golf Club of } \\
\text { Qinghewan }\end{array}$ & golf course & $116.384^{\circ} \mathrm{E}$ & $40.035^{\circ} \mathrm{N}$ & 5.3 & 4.2 & 5.2 & 4.7 \\
\hline 8 & $\begin{array}{l}\text { Golf Club of } \\
\text { Wanliu }\end{array}$ & golf course & $116.284^{\circ} \mathrm{E}$ & $39.975^{\circ} \mathrm{N}$ & 4.7 & 3.7 & 5.2 & 4.4 \\
\hline 9 & $\begin{array}{l}\text { Pine Forest in } \\
\text { Yuanmingyuan } \\
\text { Park }\end{array}$ & $\begin{array}{l}\text { needle-leaved } \\
\text { evergreen forest }\end{array}$ & $116.298^{\circ} \mathrm{E}$ & $39.999^{\circ} \mathrm{N}$ & 3.6 & 3.3 & 4.3 & 3.9 \\
\hline 10 & $\begin{array}{l}\text { Pine forest in Bajia } \\
\text { park }\end{array}$ & $\begin{array}{l}\text { needle-leaved } \\
\text { evergreen forest }\end{array}$ & $116.332^{\circ} \mathrm{E}$ & $40.02^{\circ} \mathrm{N}$ & 3.5 & 3.6 & 4.6 & 3.7 \\
\hline 11 & $\begin{array}{l}\text { Aspen grove in } \\
\text { Bajia park }\end{array}$ & $\begin{array}{l}\text { deciduous } \\
\text { broad-leaved forest }\end{array}$ & $116.326^{\circ} \mathrm{E}$ & $40.017^{\circ} \mathrm{N}$ & 4.3 & 3.5 & 4.6 & 4.2 \\
\hline 12 & $\begin{array}{l}\text { Aspen grove in } \\
\text { Beitucheng park }\end{array}$ & $\begin{array}{l}\text { deciduous } \\
\text { broad-leaved forest }\end{array}$ & $116.355^{\circ} \mathrm{E}$ & $39.975^{\circ} \mathrm{N}$ & 4.1 & 3.2 & 4.8 & 4.1 \\
\hline 13 & $\begin{array}{l}\text { Shrubs on the } \\
\text { West Mountain }\end{array}$ & mixed green space & $116.253^{\circ} \mathrm{E}$ & $40.024^{\circ} \mathrm{N}$ & 4.6 & 3.8 & 5.3 & 5.1 \\
\hline 14 & $\begin{array}{l}\text { Mixed forest in } \\
\text { Olympic Park }\end{array}$ & mixed green space & $116.381^{\circ} \mathrm{E}$ & $40.019^{\circ} \mathrm{N}$ & 3.7 & 3.4 & 4.2 & 3.8 \\
\hline
\end{tabular}




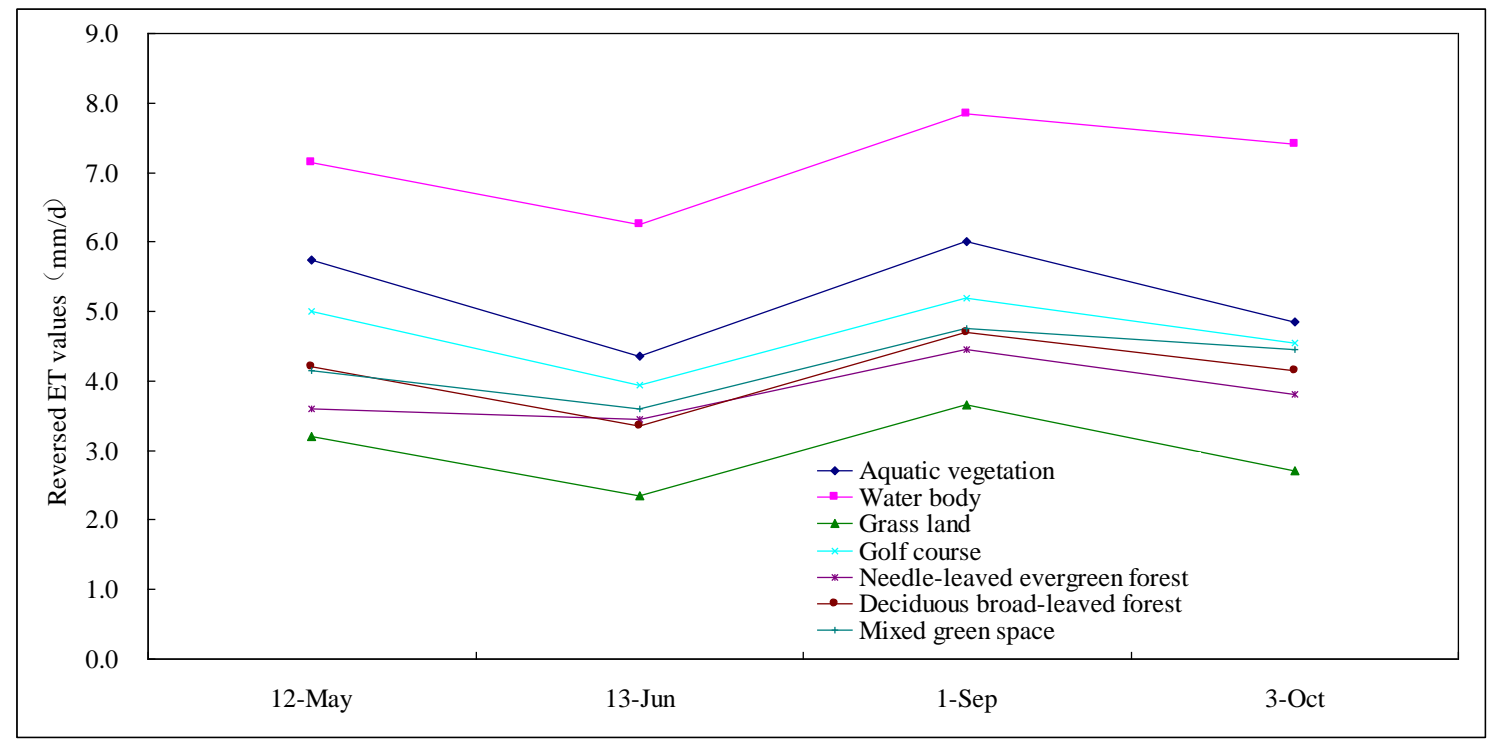

Fig. 15 Reversed ET changing trends for different vegetation

Tab. 5 Daily ET values in different seasons for different vegetation

\begin{tabular}{|c|c|c|c|c|c|c|c|}
\hline Date & $\begin{array}{c}\text { Aquatic } \\
\text { vegetation } \\
(\mathbf{m m} / \mathbf{d})\end{array}$ & $\begin{array}{c}\text { Water } \\
\text { body } \\
(\mathrm{mm} / \mathrm{d})\end{array}$ & $\begin{array}{c}\text { Grass land } \\
(\mathbf{m m} / \mathbf{d})\end{array}$ & $\begin{array}{c}\text { Golf } \\
\text { course } \\
(\mathrm{mm} / \mathrm{d})\end{array}$ & $\begin{array}{c}\text { Evergreen } \\
\text { needle-leaved } \\
\text { forest }(\mathbf{m m} / \mathbf{d})\end{array}$ & $\begin{array}{c}\text { Deciduous } \\
\text { broad-leaved } \\
\text { forest }(\mathbf{m m} / \mathbf{d})\end{array}$ & $\begin{array}{c}\text { Mixed } \\
\text { green } \\
\text { space } \\
(\mathrm{mm} / \mathrm{d})\end{array}$ \\
\hline 12-May & 5.8 & 7.2 & 3.2 & 5 & 3.6 & 4.2 & 4.2 \\
\hline 13-Jun. & 4.4 & 6.3 & 2.4 & 4 & 3.5 & 3.4 & 3.6 \\
\hline 1-Sep. & 6 & 7.9 & 3.7 & 5.2 & 4.5 & 4.7 & 4.8 \\
\hline 3-Oct. & 4.9 & 7.4 & 2.7 & 4.6 & 3.8 & 4.2 & 4.5 \\
\hline Average & 5.3 & 7.2 & 3 & 4.7 & 3.9 & 4.1 & 4.3 \\
\hline
\end{tabular}

\subsubsection{Region water consumption quantity estimation}

The reversed daily ET values on typical days for representative vegetation types and the vegetation classification results were used to attain the quantity of the water consumed in the growing season and three assumptions accompanied this extrapolation. (1) The monthly average ET value for typical vegetation might be presented by the ET value on typical day. (2) Due to the influence of the clouds coverage, there were no available imagines in July and August and the monthly average ET values in two months were interpolated from the ET values in June and September. (3) The growing season for green land vegetation is from May $1^{\text {st }}$ to Oct. $31^{\text {th }}$.

The monthly water consumption was attained by multiplying the areas which were derived from the RapidEye imagine, daily ET values for typical vegetation which 
were derived from the reversed ET maps and the day numbers in the month. By summarizing the monthly water consumption, the total quantity for water consumed by green land in the growing season was attained.

Tab. 6 Quantity of water consumed by different vegetation in different seasons

\begin{tabular}{|c|c|c|c|c|c|c|c|c|}
\hline Vegetation type & $\begin{array}{l}\text { Area } \\
\mathbf{k m}^{2}\end{array}$ & $\begin{array}{l}\text { May } \\
\mathbf{M m}^{3}\end{array}$ & $\begin{array}{l}\text { Jun. } \\
\mathbf{M m}^{3}\end{array}$ & $\begin{array}{c}\text { Jul. } \\
\mathbf{M m}^{3}\end{array}$ & $\begin{array}{l}\text { Aug. } \\
\mathbf{M m}^{3}\end{array}$ & $\begin{array}{l}\text { Sep. } \\
\mathrm{Mm}^{3}\end{array}$ & $\begin{array}{l}\text { Oct. } \\
\mathbf{M m}^{3}\end{array}$ & $\begin{array}{l}\text { Sum } \\
\mathbf{M m}^{3}\end{array}$ \\
\hline Aquatic vegetation & 0.82 & 0.15 & 0.11 & 0.12 & 0.14 & 0.15 & 0.12 & 0.79 \\
\hline Grass land & 8.63 & 0.86 & 0.61 & 0.74 & 0.86 & 0.94 & 0.72 & 4.74 \\
\hline Golf course & 1.45 & 0.22 & 0.17 & 0.20 & 0.22 & 0.23 & 0.20 & 1.24 \\
\hline $\begin{array}{l}\text { Evergreen needle- } \\
\text { leaved forest }\end{array}$ & 5.31 & 0.61 & 0.55 & 0.62 & 0.68 & 0.71 & 0.64 & 3.81 \\
\hline $\begin{array}{l}\text { Deciduous } \\
\text { broad-leaved forest }\end{array}$ & 23.24 & 3.03 & 2.34 & 2.74 & 3.06 & 3.28 & 2.99 & 17.43 \\
\hline Mixed green space & 17.4 & 2.24 & 1.88 & 2.15 & 2.36 & 2.48 & 2.40 & 13.52 \\
\hline Sum & 56.87 & 7.10 & 5.65 & 6.58 & 7.31 & 7.79 & 7.09 & 41.52 \\
\hline
\end{tabular}

The results showed that the quantities of the water consumed by the green land in different months were shown in Tab. 6 and the total quantity is $41.52 \mathrm{Mm}^{3}$ in the growing season. The highest value appeared in September with the value of $7.79 \mathrm{Mm}^{3}$ and the minimum value appeared in June with the value of $5.65 \mathrm{Mm}^{3}$. According to the statistic results, the deciduous broad-leaved forest consumed the most water with the value of $17.43 \mathrm{Mm}^{3}$ followed by the mixed green space with the value of 13.52 $\mathrm{Mm}^{3}$, the grass land with the value of $4.74 \mathrm{Mm}^{3}$, the evergreen needle-leaved forest with the value of $3.81 \mathrm{Mm}^{3}$, the golf course with the value of $1.24 \mathrm{Mm}^{3}$ and the aquatic vegetation with the value of $0.79 \mathrm{Mm}^{3}$.

These results were compared with other related research resulsts. Based on the green land survey data and the experiment results of the 35 commonly used planting species in Beijing, Che (2008) used the DBH (Diameter at Breast Height) of arborswater utilization model and the LAI - water utilization model to estimate the quantity of water consumed by the green land in 6 districts in Beijing urban region. The total yearly water consumed by the green land is $389 \mathrm{Mm}^{3}$ from this method and the area of the 6 districts is about $1368 \mathrm{~km}^{2}$. Supposing the water consumption is proportional to the area of region, and the water consumption would be $41.94 \mathrm{Mm}^{3}$ using Che's 
method, accounting for the studying area is $147.5 \mathrm{~km}^{2}$. The difference between the result from Che's method and the result from our method is less than $1.0 \%$.

Based on the water consumption characteristics of typical vegetation green, the green land areas extracted from remote sensing imagines, and the investigation data, Di et al. (2012) estimated that the water consummated by the green land is about 161 $\mathrm{Mm}^{3}$ and the total green land area is about $197.3 \mathrm{~km}^{2}$ within the $5^{\text {th }}$ Ring Road in Beijing urban area. Supposing the water consumption is proportional to the area of green land, the water consumption would be $46.41 \mathrm{Mm}^{3}$ by Di's method, accounting for the green land area is $56.87 \mathrm{~km}^{2}$ in the studying region. The difference between the result from Di's method and the result from our method is $11.8 \%$. Therefore, the results from Che's method, Di's method and our method were quite similar.

\section{Summery and conclusion}

The remote sensing technology is of crucial importance for urban green land classification and regional water consumption estimation in the large region. In this article, this case studying was carried out in the Northwest region of Beijing City and the study area covered about $147.5 \mathrm{~km}^{2}$. This study was based on high resolution remote sensing imagines, meteorology data and water consumption experiment results. The following processes were included: (1) the green land region was derived from the high spatial-resolution RapidEye imagine by using Stratified Classification method; (2) Vegetation types were identified by using Object-oriented Classification method;(3) The daily ET values were reversed by using Surface Energy Balance Algorithm for Land (SEBAL) model; (4) The regional ET spatial patterns and the water consumption temporal patterns for different vegetation were analyzed based on multi-temporal daily ET maps, further, the total quantity of water consumption in the studying region was estimated.

The area of green land was $56.87 \mathrm{~km}^{2}$ accounting for $31 \%$ of urban area. Further, the green land was divided into 6 classes: deciduous broad-leaved forest, needle-leaved evergreen forest, mixed green space, golf course, grass land, aquatic 
vegetation and the areas were $23.24 \mathrm{~km}^{2}, 5.31 \mathrm{~km}^{2}, 0.82 \mathrm{~km}^{2}, 8.63 \mathrm{~km}^{2}, 1.45 \mathrm{~km}^{2}$, $17.42 \mathrm{~km}^{2}$, respectively.

The regional daily ET values were reversed using SEBAL model on 4 typical days (May 12 $2^{\text {th }}$, Jun. $13^{\text {th }}$, Sep. $1^{\text {th }}$ and Oct. $3^{\text {th }}$ in 2013) and the ET spatial distribution patterns were analyzed. The average daily ET values for different vegetations from high to low were aquatic vegetation, golf course, mixed green space, deciduous broad-leaved forest, needle-leaved evergreen forest, grass land and the average daily ET values were $5.3 \mathrm{~mm} / \mathrm{d}, 4.7 \mathrm{~mm} / \mathrm{d}, 4.3 \mathrm{~mm} / \mathrm{d}, 4.1 \mathrm{~mm} / \mathrm{d}, 3.9 \mathrm{~mm} / \mathrm{d}, 3.0 \mathrm{~mm} / \mathrm{d}$ respectively. Compared with the water consumption experiment result of the typical vegetation, the mean relative error for reversed ET values based SEBAL model was about $7.9 \%$.

Through temporal interpolation, the total water consumption quantity for the green land in studying region in the growing period was attained and the value was 41.52 $\mathrm{Mm}^{3}$. The quantity of water consumed for different vegetations from high to low were deciduous broad-leaved forest, mixed green space, grass land, needle-leaved evergreen forest, golf course, the aquatic vegetation and the values were $17.43 \mathrm{Mm}^{3}$, 13.52 $\mathrm{Mm}^{3}, 4.74 \mathrm{Mm}^{3}, 3.81 \mathrm{Mm}^{3}, 1.24 \mathrm{Mm}^{3}, 0.79 \mathrm{Mm}^{3}$, respectively.

More and more remote sensing data with different spatial, spectral and temporal resolution is becoming available, and it would provide abundance regional information which is helpful for estimating water consumption and vegetation classification, meanwhile, the estimation method based on RS imagines is on real-time and dynamically monitoring regional water consumption with lower cost.

However, the commonly used imagines in ET reversing method included: visible band, near infrared band, thermal infrared band imagine and these imagines could not be obtained under cloudy conditions. The hybrid estimation method with the remote sensing imagines and the meteorological data might overcome these barriers. Further, the radar imagines or lidar imagines were little influenced by the clouds, and they might provide more information on vegetation status, green land structure, and soil water status, as well as water consumption. 
In this study, the Landsat8 OLI imagines of $30 \mathrm{~m}$ resolution and TIRS imagines of $100 \mathrm{~m}$ were used to reverse regional daily ET values. However, the land covers in urban area were highly heterogeneous, within a pixel area, there might be different land covers such as build ups, road, bare soil which might have influence on ET values of green land. Mixed pixel problem should be taken into account in further research and the ET values in sub-pixel scale should be estimated according to the area contribution of different land covers. Therefore, the regional ET results are expected to be more accurate and to be more helpful in water resource management.

\section{Acknowledgement}

This work was partly supported by Beijing Municipal Science and Technology Commission funding for two related projects under Grant D161100005916003 and Z161100001116104. It was also partly funded by the Beijing Water Authority outstanding young talent project (2015), the Beijing Municipal Organization Department young talent project (2016) as well as the International Science \& Technology, Cooperation Program of China under Grant 2014DFE10220.

\section{References}

1. Bastiaanseen W. G. M. SEABAL-based Sensible and Latent Heat Fluxes in the Irrigated Gediz Basin, Turkey[J]. Journal of Hydrology, 2000, 229: 87-100.

2. Bastiaanssen W. G. M., M. Menenti, R. A. Feddes and A. A. M. Holtslag. A Remote Sensing Surface Energy Balance Algorithm for Land (SEBAL) 1. Formulation [J]. Journal of Hydrology, 1998, 212-213: 198-212.

3. Che Wenrui. Annual Water Utilization Estimation of Main Trees, Shrubs and Lawn Grass Species of Greenland in Beijing [D]. Master dissertation. Beijing: Beijing Forest University, 2008, 59-60.

4. Cheng, Wenxin and Y. Kang. Measuring Method of Water Consumption and Water Requirement of Lawn in Beijing Area [J]. Journal of Water Saving Irrigation, 2002, 5:12-15. (In Chinese)

5. Cleugh, H., R. Leuning, Q. Mu and S. W. Running. Regional Evaporation Estimates from Flux Tower and MODIS Satellite Data [J]. Remote Sensing of Environment, 2007, 106(3): 285-304.

6. Di, Suchuang, W. Wu, H. Liu and X. Pan. Greenland water consumption estimation and evapotranspiration inversion within 5th Ring Road in Beijing city [J]. Transactions of the Chinese Society of Agricultural Engineering, 2012, 28(10): 98-102. (in Chinese)

7. Jia, Z., S. Liu, Z. Xu, Y. Chen and M. Zhu. Validation of Remotely Sensed Evapotranspiration over the Hai River Basin, China [J]. Journal of Geophysical Research, 2012, 117: 2156-2202.

8. Jiang, L. and S. Islam. Estimation of Surface Evaporation Map over Southern Great Plains Using Remote Sensing Data [J]. Water Resource Research, 2001, 37: 329-340. 
9. Kim, H. W., K. Hwang, Q. Mu, S. O. Lee and M. Choi. Validation of MODIS 16 Global Terrestrial Evapotranspiration Products in Various Climates and Land Cover Types in Asia [J]. KSCE Journal of Civil Engineering, 2012, 16(2): 229-238.

10. Li, Z.-L., R. L. Tang, Z. Wan, Y. Bi, C. Zhou, B. Tang, G. Yan and X. Zhang. A Review of Current Methodologies for Regional Evapotranspiration Estimation from Remotely Sensed Data [J]. Sensors, 2009, 9: 3801-3853.

11. Lu, Jing, R. L. Tang, H.Tang and Z.-L. Li. Derivation of Daily Evaporative Fraction Based on Temporal Variations in Surface Temperature, Air Temperature, and Net Radiation [J]. Remote Sensing, 2013, 5: 5369-5396.

12. Lu, Jing, Z.-L. Li, R. L. Tang, B.-H. Tang, H. Wu, F. Yang, J. Labed and G. Zhou. Evaluating the SEBS-estimated Evaporative Fraction from MODIS Data for a Complex Underlying Surface [J]. Hydrological Processes, 2013, 27 (22): 3139-3149.

13. Ma da, J. Li and P. Lin. Primary Studies on Water Consumption of Man-made Forest in Mountain Area in Beijing [J]. Journal of Shanxi Agricultural University, 2006, (1): 48-51. (In Chinese)

14. Meng, Fanrong, F. Qiao and Z. Zhang. Comparison of Transpiration Water Consumption by Three Landscape Tree Species in Urban Areas of Beijing [J]. Journal of Fujian College of Forestry, 2005, 25(2): 176-180. (In Chinese)

15.Mu, Q., F. A. Heinsch, M. Zhao and S. W. Running. Development of a Global Evapotranspiration Algorithm Based on MODIS and Global Meteorology Data [J]. Remote Sensing of Environment, 2007, 111(4): 519-536.

16. Mu, Q., M. Zhao and S. W. Running. Improvements to a MODIS Global Terrestrial Evapotranspiration Algorithm [J]. Remote Sensing of Environment, 2011, 115(8): 1781-1800.

17. Pan, Zhiqiang and G. Liu. Evapotranspiration Research of Yellow River Delta Using Remote Sensing Method [J]. Geo-information Science. 2003(3):91-96.

18. Qiao, Pinglin, J. Zhang and C. Wang. The Method for Retrieving Evapotranspiration Based on Remote Sensing Data of the Shiyang River Basin[J]. Journal of Arid Land Resources and Enviroment, 2007, 21(4):107-110.

19. Statistical Bureau of Beijing City. Beijing Statistical Year Book [EB/OL], 2013, http://www.bjstats. gov.cn/nj/main/2014-tjnj/CH/index.htm.

20. Su, Z. The Surface Energy Balance System (SEBS) for Estimation of Turbulent Heat Fluxes [J]. Hydrology and Earth System Sciences, 2002, 6: 85-99.

21. Tang, Ronglin, Z.-L. Li, K. S. Chen, Y. Jia, C. Li and X. Sun. Spatial-scale Effect on the SEBAL Model for Evapotranspiration Estimation Using Remote Sensing Data [J]. Agricultural and Forest Meteorology, 2013, 174: 28-42.

25. Tang, Ronglin, Z.-L. Li, and X. Sun. Temporal upscaling of instantaneous evapotranspiration: An intercomparison of four methods using eddy covariance measurements and MODIS data [J]. Remote Sensing of Environment, 2013, 138, 102-118.

22. Tang, Ronglin, Z.-L. Li, Y. Jia, C. Li, X. Sun, W. P. Kustas and M. C. Anderson. An Intercomparison of Three Remote Sensing-based Energy Balance Models Using Large Aperture Scintillometer Measurements over a Wheat-corn Production Region [J]. Remote Sensing of Environment, 2011, 115(12): 3187-3202.

23. Wei, Tianxing, J. Zhu, X. Zhang, K. He and Z. Gao. The Regularity of Water Consumption of Black Locust and Chinese Pine on Loess Slope in Southwestern of Shanxi Province [J]. Journal of Beijing Forest University, 1998, 20(4): 36-40. (In Chinese) 
24. Zeng Lihong, K. Song, B. Zhang and J. Du. Applying Landsat Data and SEBAL Model to Inverse Regional Evapotranspiration and Its Parameters Estimation [J]. Remote Sensing Technology and Application, 2008, 23(3), 255-263. 